\title{
REVIEW
}

\section{Analytical Challenges for Identification of New Psychoactive Substances \\ A Literature-Based Study for Seized Drugs}

Aline Thais Bruni1,2* $\triangle$, Caio Henrique Pinke Rodrigues ${ }^{1}$ iD, Christiano dos Santos $^{1}$ iD, Jade Simões de Castro' ${ }^{1}$, Livia Salviano Mariotto' ${ }^{1}$, Luiz Felipe Colli Sinhorini' ${ }^{1}$ (D)

${ }^{1}$ Departamento de Química, Faculdade de Filosofia, Ciências e Letras de Ribeirão Preto, USP. Avenida

Bandeirantes, 3900, Monte Alegre, Ribeirão Preto, SP, Brazil

${ }^{2}$ Instituto Nacional de Ciência e Tecnologia Forense (INCT-Forense)

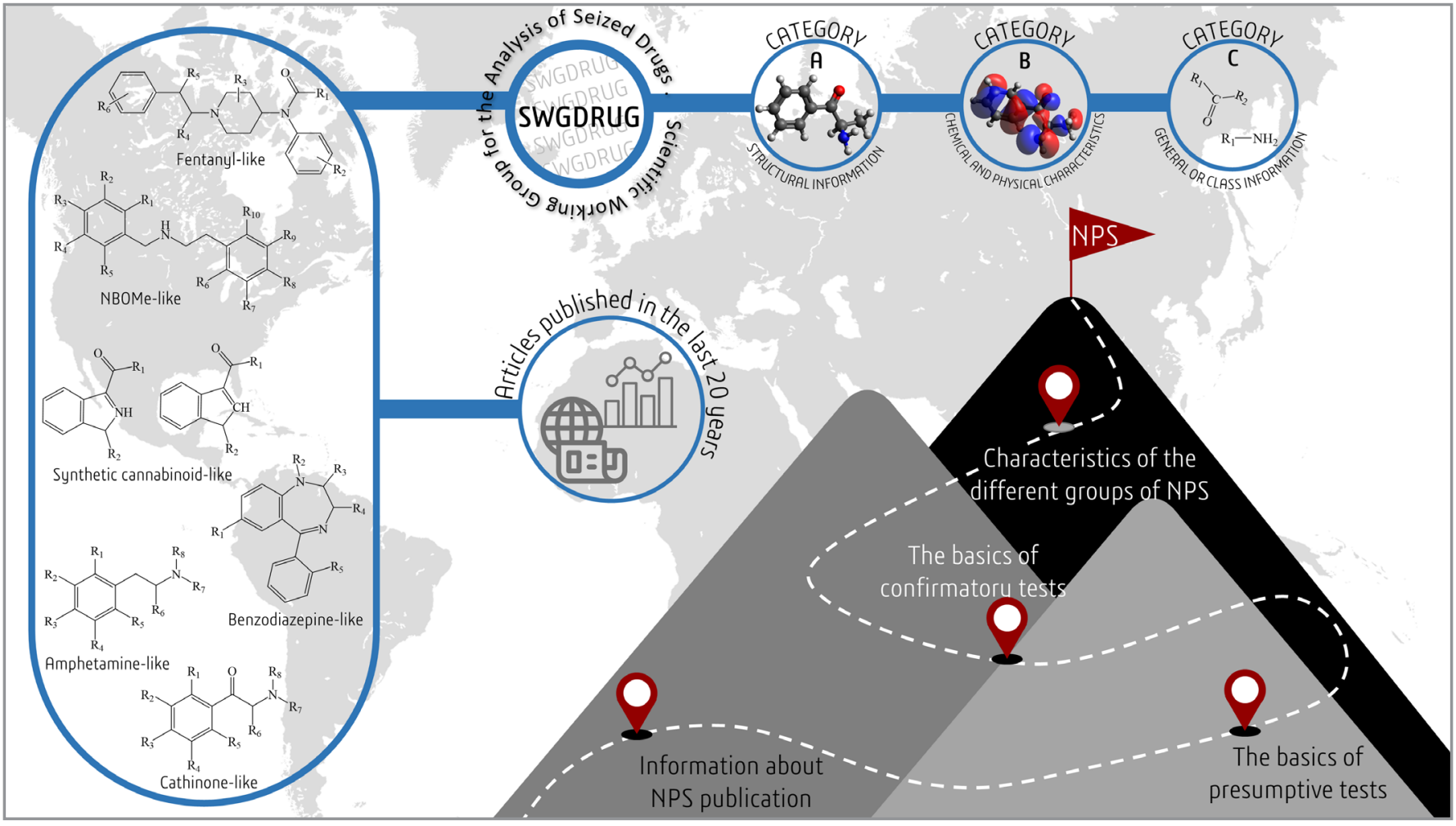

Correct identification of substances is essential to understand drug use and trafficking trends and guide measures for harm reduction and treatment. Two steps are needed to verify the nature of a substance properly: a presumptive test and a confirmatory test. There are presumptive tests which presents deficiencies, such as providing false-positive and false-negative results. Confirmatory tests are more reliable,

Cite: Bruni, A. T.; Rodrigues, C. H. P.; dos Santos, C.; de Castro, J. S.; Mariotto, L. S.; Sinhorini, L. F. C. Analytical Challenges for Identification of New Psychoactive Substances: A Literature-Based Study for Seized Drugs. Braz. J. Anal. Chem., 2022, 9 (34), pp 52-78. doi: http://dx.doi.org/10.30744/brjac.2179-3425.RV-41-2021

Submitted 23 March 2021, Resubmitted 09 July 2021, $2^{\text {nd }}$ time Resubmitted 30 July 2021, $3^{\text {rd }}$ time Resubmitted 06 August 2021 , Accepted 16 August 2021, Available online 29 September 2021. 
but they are more expensive. With the appearance of New Psychoactive Substances (NPS), identifying and characterizing illicit substances has become more challenging. This paper focuses on presenting information about NPS characteristics and analysis. For this purpose, we have reviewed the literature to address the main aspects of five groups of NPS: amphetamine-type stimulants, synthetic cannabinoids, $\mathrm{N}$-methoxybenzyl-methoxyphenylethylamine (NBOMe), synthetic opioids, and benzodiazepines. We present the main characteristics of each group and certain aspects of presumptive and confirmatory tests regarding these groups. Our findings show obstacles in developing methodologies that can correctly identify these substances, and problems can increase as new structures appear. This information can be helpful to drive research into identifying NPS and inform law enforcement and law practitioners about the main characteristics of each group and the main questions involving their identification.

Keywords: New Psychoactive Substances, presumptive tests, confirmatory tests, amphetamine-type stimulants, synthetic cannabinoids, NBOMes, synthetic opioids, synthetic benzodiazepines.

\section{Abbreviations}

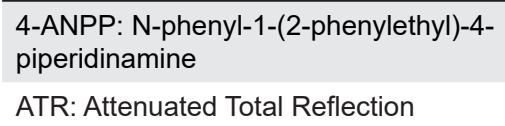

ATR: Attenuated Total Reflection

ATS: Amphetamine-Type Stimulants

CBD: Cannabidiol

CBN: Cannabinol

DAPPI: Desorption atmospheric pressure photoionization

DART-MS: Direct analysis in real-time mass spectrometry

DAT: Dopamine transporter

DESI-MS: Desorption electrospray ionization with mass spectrometry

DOA: Drugs of abuse

\section{EU: European Union}

FBB: Fast Blue B

FBBB: Fast Blue BB

FITC: Fluorescein isothiocyanate

FTIR: Fourier transform infrared

GC-FID: Gas chromatography with flame ionization detector

GC-IRD: Gas chromatography with infrared detector
GC-MS: Gas chromatography with mass detector

GC-MS-El: Gas chromatography with cold electron ionization

HPLC: High-performance liquid chromatography

HPLC-AD: High-performance liquid chromatography coupled to amperometric detector

HPLC-UV: High-performance liquid chromatography coupled to ultraviolet detector

HRMS: High-resolution mass spectrometry

IMS: Ion mobility spectrometry

IR: Infrared spectroscopy

LC-HRMS: Liquid chromatography coupled to high-resolution mass spectrometry

LC-MS: Liquid chromatography coupled to mass spectrometry

LLE: Liquid-liquid extraction

LSD: Lysergic acid diethylamide

MALDI-TOF-MS: Matrix-assisted laser desorption/ionization mass spectrometry

MDMA: Methylenedioxymethamphetamine

NET: Norepinephrine transporter

NMR: Nuclear magnetic resonance

NPF: Nonpharmaceutical Fentanyl
NPS: New Psychoactive Substances

NSO: New Synthetic Opioids

MS: Mass spectrometry

PP: Protein precipitation

Rf: Retention factors

SERT: Serotonin transporter

SPE: Solid-phase extraction

SWGDRUG: Scientific Working Group for the Analysis of Seized Drugs

TD-DART-MS: Thermal desorption in realtime mass spectrometry

THC: $\Delta$ 9-tetrahydrocannabinol

TLC: Thin-layer chromatography

UHPLC: Ultra-high performance liquid chromatography

UHPLC-MS/MS: Ultra-high performance liquid chromatography coupled to mass spectrometry

UK: United Kingdom

UNODC: United Nations Office on Drugs and Crime

UPLC-MS: Ultra-performance liquid chromatography coupled to mass spectrometry

USA: United States of America 


\section{INTRODUCTION}

The use of recreational drugs of abuse (DOA) has always been present in different historical moments and societies and has increased over the years. Excessive prohibition of substance use in the drug war model has produced and consolidated illegal markets controlled by criminals [1]. Drug war prohibitions and policies have created a phenomenon that has given rise to New Psychoactive Substances (NPS) [2,3], which bear structural modifications of well-known substances such as cocaine, lysergic acid diethylamide (LSD), and cannabis, among others. The idea behind NPS is to provide the consumer with an alternative that is both recreational and non-illegal. According to the United Nations Office on Drugs and Crime (UNODC), 899 NPS were reported between 2009 and 2018 worldwide, and that number continues to grow $[4,5]$.

Drug regulation mainly deals with conventional substances, and the prohibition is based on specific structural information. Because of this, most NPS are under-regulated: as the legislation starts to target newly discovered structures, new analogous substances or derivatives continue to emerge to circumvent the regulations, in a faster movement than the legal system and regulatory agencies can cope with [6]. Countries are using a total ban on structural classes as an alternative procedure [7-9]. Nevertheless, this strategy has disadvantages; for example, access to more detailed research into NPS may be unavailable, not to mention that an unregulated and unrestricted market can cause as much damage as the prohibitive model $[2,10,11]$.

The rise of NPS represents a challenge for both legal control and health. From the legal aspect, scientific knowledge about these substances is lacking. Classifications for controlling psychoactive substances consider factors related to culture, production, manufacturing, consumption, market, and factors that can be characteristic of the country. However, prohibitions lack a scientific basis given that there are not enough studies to prove the harmful effects of these substances on the user or the society. Science is rarely part of the decision-making process and, when it can offer recommendations, they are seldom considered. If the undesirable effects of a specific substance cannot be proven, showing its possible benefits is beyond the scope of the evaluation. Without a scientific basis for establishing harm or benefits, the repression associated with a particular substance can be disproportionate and require a great deal of effort in law enforcement. Thus, NPS monitoring demands forensic, toxicological, and clinical data [12-14].

The conventional drug monitoring model considers only a small number of well-known and controlled substances. Forensic and toxicological analytical approaches can detect, identify, and, depending on the technique, quantify substances in seized or biological samples. It is essential to understand that the traditional way of responding to illicit drugs may not suit NPS [14]. In forensic terms, proper identification of substances is crucial when assessing suspect seized samples and evaluating cases of possible intoxication and requires reliable and accurate identification methods [6].

Among other factors, knowing the effects of using a particular drug can be necessary to elucidate postmortem aspects and to assist in cases involving drug-facilitated crimes. Drugs can have consequences concerning human behavior, leading to consequences within the legal system [15]. Drug detection in biological samples can present problems. The lack of pharmacokinetic and pharmacodynamic knowledge can compromise the identification of metabolites $[14,16]$.

From the analytical point of view, the correct identification of NPS is a significant challenge. The difficulties inherent in NPS evaluation include the diversity of changes to molecules and the speed with which they appear in the market. New molecules emerge faster than the development of analytical protocols. One of the main problems is the lack of certified standards for reference [14].

Analytical protocols involve presumptive detection, which is usually qualitative, and later confirmation [16]. Presumptive detection methods are called presumptive or field tests. These tests allow rapid and low-cost identification in both the clinical and forensic fields and indicate the presence or absence of a substance of interest and drug abuse. They can identify a particular group of chemicals, but they are not selective enough to indicate the substance within the group. They have advantages such as not requiring specific training, equipment, or sample preparation and being highly sensitive and portable, facilitating 
substance identification on site. These characteristics and advantages have enabled their extensive use for law enforcement despite their low discretion performance [16-20]. With the increase in drug-facilitated crimes and addiction, these tests may be useful in point-of-care for harm reduction actions [21,22].

For law enforcement, a confirmatory test is required after presumptive identification to establish the chemical nature of the substance(s). Confirmatory drug identification is more trustful than presumptive tests. However, confirmatory tests demand sophisticated analytical equipment, specialized knowledge, and complex sample preparation, which can be destructive [14,23,24].

The appearance of new drugs has been increasing. Legal actions to try to control these substances have not been enough to stop their production. It is necessary to understand their diversity and to develop analytical methods to identify them. Analytical methods developed for classic drugs may not be able to identify these substances correctly $[26,27]$.

Enhancing the use of accepted and validated scientific practices involving accurate and reliable analytical methods requires time. It may not keep pace with the appearance of these substances in realtime. Analytical techniques and methodologies shall be able to help to understand how the drug market evolves. Trustful methods shall assure that the new compounds can be correctly determined. Furthermore, producing or acquiring reference standards is essential $[6,15,25]$. All these situations share challenges: correctly identifying substances, obtaining standards for comparison, assessing the toxicological potential associated with them, and establishing harm reduction mechanisms.

This paper aims to provide an overview of five groups of synthetic classes of NPS: amphetamine-type stimulants (amphetamines and cathinones), cannabinoids, N-methoxybenzyl-methoxyphenylethylamine (NBOMe), opioids, and benzodiazepines. These sets comprise stimulants, hallucinogens, and depressants [28]. The overall idea is to present the characteristics of each group and particularities regarding their testing. This paper does not aim to exhaust the subject, but the intention is to show that there is a lot to learn about these substances. The information presented here can help the reader interested in drug analysis to understand the issue of NPS diversity and how it affects the identification of these substances. It can be helpful to increase the knowledge of researchers, forensic scientists, and law practitioners about these substances.

\section{METHOD}

We conducted a literature-based review to collect information about NPS. We delimited our research into four sections:

- Section I: Information about NPS publication. This section shows the interest in publishing research about NPS. We performed a search of both the SCOPUS and Web of Science databases. First, we focused on the broad publications by using the search keyword "New Psychoactive Substances", and the keywords regarding the groups of synthetic substances amphetamines, cathinones, cannabinoids, NBOMes, opioids, and benzodiazepines. We also collected information about presumptive and confirmatory tests for the previous keywords. This search was delimited in a twenty-year interval.

- Section II: The basics of presumptive tests. This section provides an overview of presumptive tests for drugs.

- Section III: The basics of confirmatory tests. This section presents information about the main confirmatory tests for use in drug identification.

- Section IV: Characteristics of the different groups of NPS. This section presents the main characteristics of each group of NPS and comments on presumptive and confirmatory tests for them.

For Sections II-IV, we collected information from academic and scientific works, social data, grey literature, institutional websites, and news published on the Internet. Most of the cited references are current ones. Around $65 \%$ of them were published in the last five years (2017-2021); 29.5\% were published after 2008 because, according to the literature, this date is related to the appearance of NPS [7,29]. The rest of the references (around 5.5\%) were necessary for background information. 


\section{Section I: Information about publication on NPS}

Figure 1 shows the SCOPUS database results. Figure 1(a) presents the overall publications for the terms "New Psychoactive Substances" and those regarding the groups of synthetic substances: amphetamines, cathinones, cannabinoids, NBOMes, opioids, and benzodiazepines. Figures 1 (b) and 1 (c) show information about presumptive and confirmatory tests for each case. Figure 2 shows information from the Web of Science database. Figures 2(a)-(c) follow the same organization presented in Figure 2.

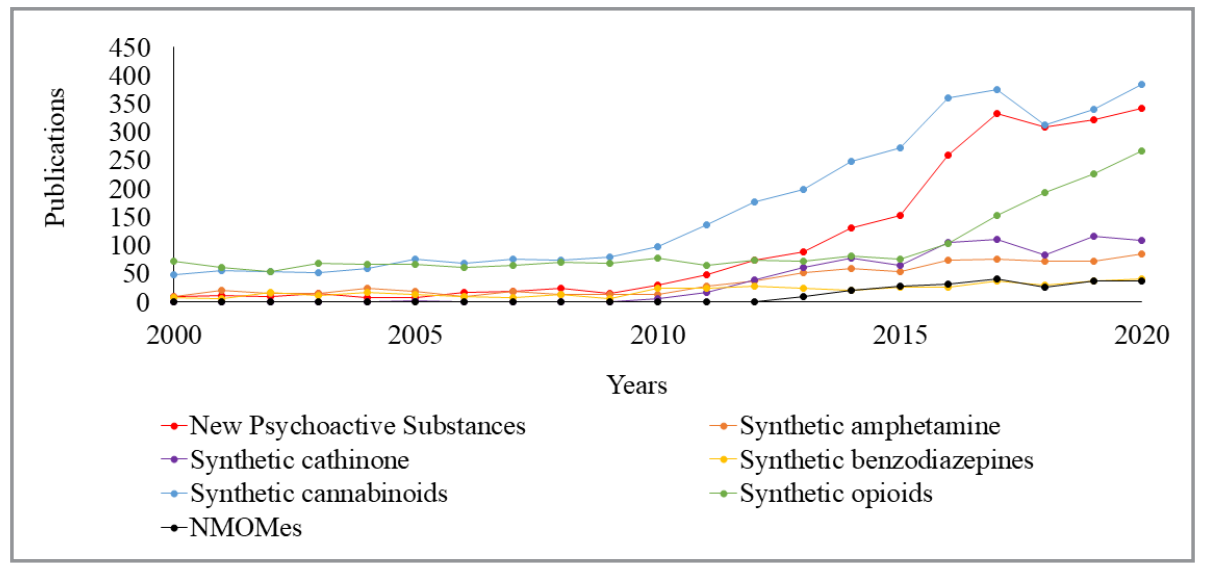

(a)

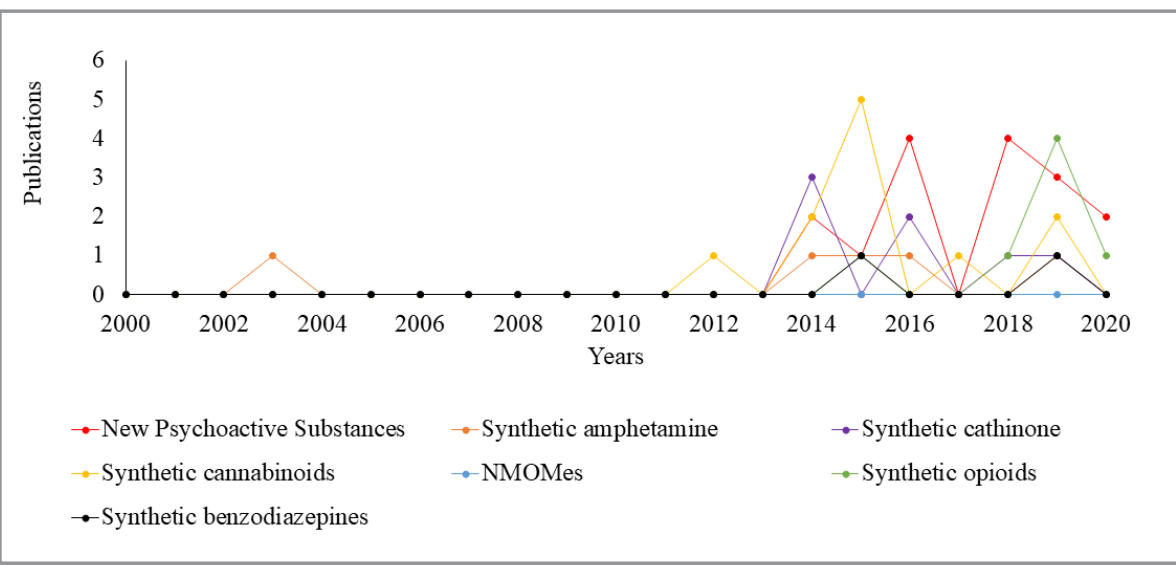

(b)

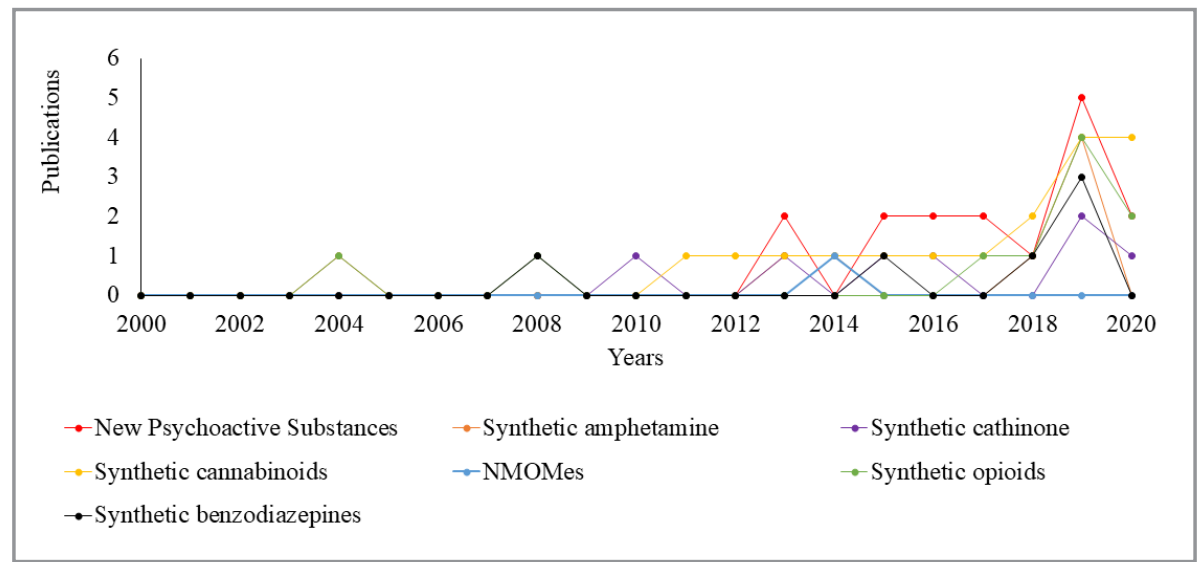

(c)

Figure 1. Articles published about NPS in the last 20 years in the SCOPUS database: (a) results for the terms "New Psychoactive Substance" and for each group of NPS; (b) results for presumptive tests; and (c) results for confirmatory tests. 


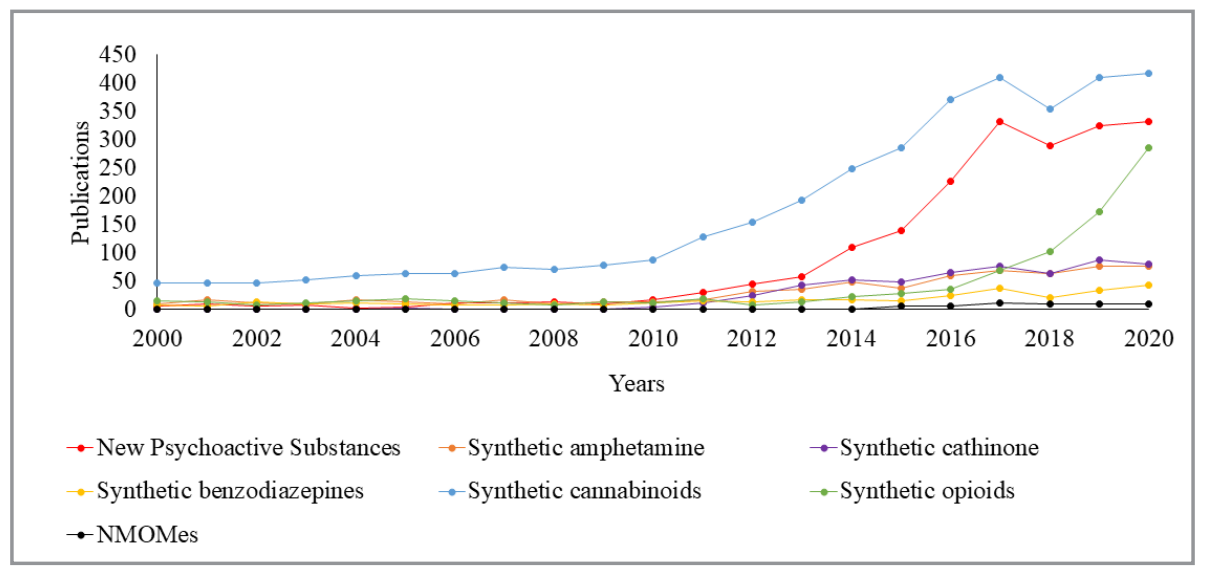

(a)

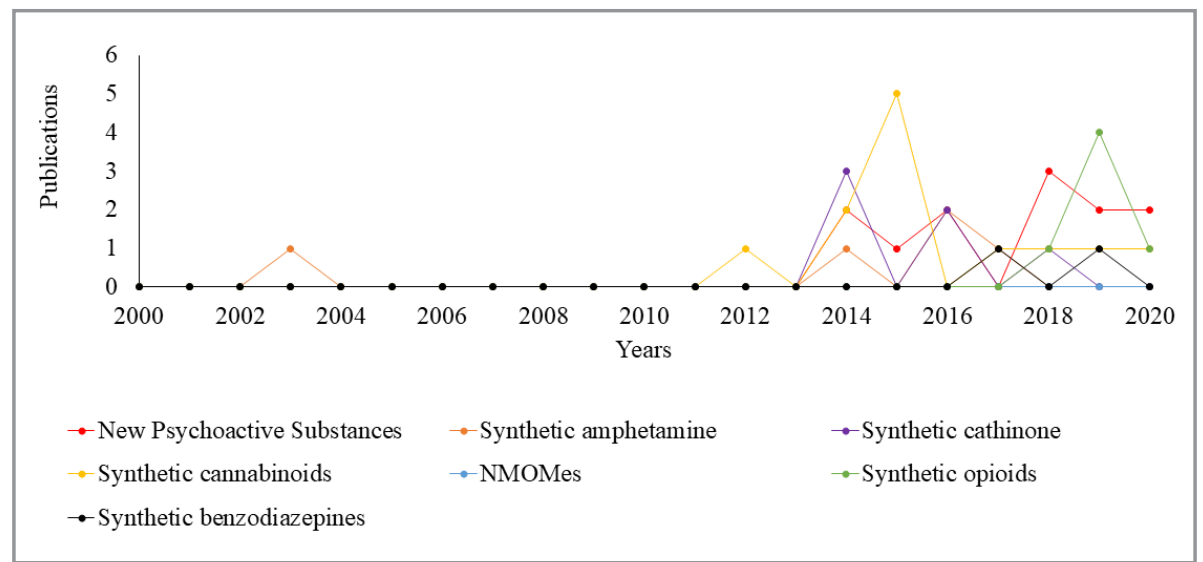

(b)

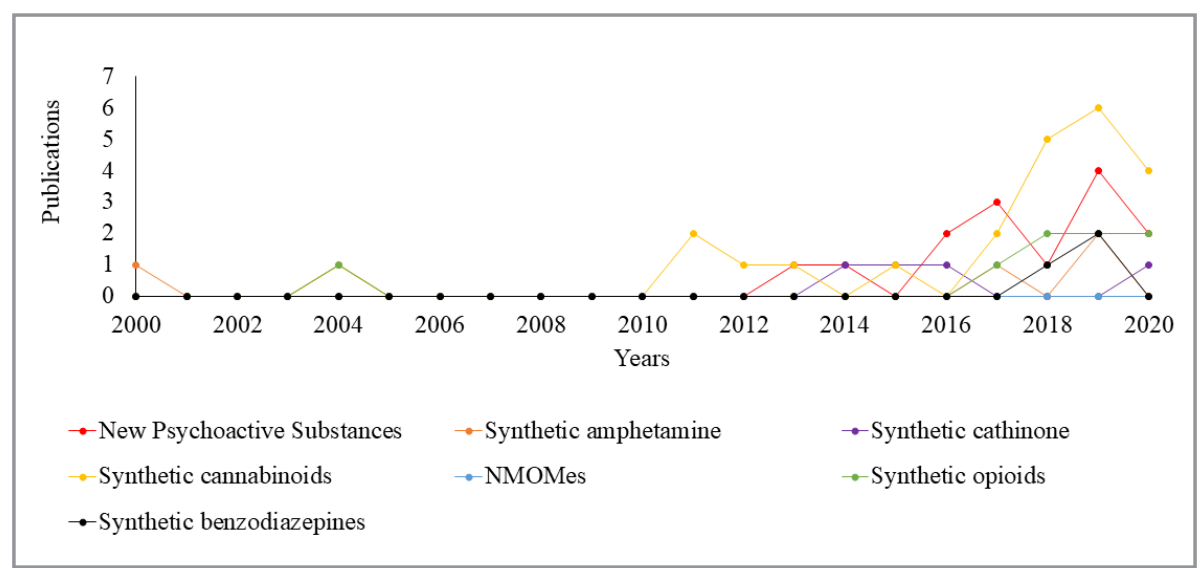

(c)

Figure 2. Articles published about NPS in the last 20 years in the Web of Science database: (a) results for the terms "New Psychoactive Substances" and for each group of NPS; (b) results for presumptive tests; and (c) results for confirmatory tests.

In both databases, we observed an overall increase in the studies for all groups of substances. Synthetic cannabinoids and synthetic opioids have received greater general interest.

Synthetic amphetamines were the first group to be studied regarding presumptive tests. We can observe similarities in the patterns for these publications in the two databases. There is no constant research production for these issues. Still concerning presumptive tests, synthetic cannabinoids are the most studied group of NPS. 
For confirmatory tests, both databases show that there have been more publications on synthetic cannabinoids. The SCOPUS database showed growing interest for most drugs, except for NBOMes. The same trend could be observed in the Web of Science dataset, where there are no publications on NBOMes. These results strengthen the importance of studying these issues for seized NPS.

\section{Section II: The basics of presumptive tests}

When a suspicious substance is found, a presumptive test is usually the first step in the analysis. This test is generally run at the place of arrest and aims to indicate the presence or absence of a suspected illicit substance. There are new technologies to run this test on-site, and portable equipment has been developed for this purpose, such as infrared and Raman spectroscopy, and mass spectrometry, which is easy to use and enables fast identification within just a few minutes. However, portable advanced analytical techniques are expensive, and the team is not expected to have this equipment available during apprehension [20,30]. Electrochemical, voltammetric, and piezoelectric devices have also been extensively tested for presumptive drug tests to allow the presence of a broader range of drugs to be determined [20,30-32].

There are several presumptive tests. Among them, colorimetric and immunoassay tests are worthy of note. Colorimetric tests are generally the most common. In this case, reagents are added to a small amount of the suspected substance, and the appearance of a specific color may indicate the presence of the illicit substance. In immunoassay tests, the alleged substance reacts with a particular antibody. This reaction is also characteristic of chemical classes [20,33]. For immunoassay tests, it is necessary to have antibodies that specifically bind to the structures. It can be a problem for NPS because of their fast emergence in the market [34].

Because colorimetric tests are low-cost, portable, and sensitive, they are widely used. Color variation occurs due to specific reactions within a functional group within a class of drugs. The color test must be selective for its class of drugs $[6,17,20,26,30]$. Despite the apparent advantage of colorimetric tests, there are concerns about their application, and agents must be aware of the possible results. A presumptive test can provide accurate results, i.e., it can correctly indicate the substance. However, false results; that is, false-positive and false-negative results, are also possible. It is undesirable because they can prevent the law from being correctly applied. For example, a false negative means that the test cannot detect the substance even if it is present in the sample. Consequently, the law cannot be enforced, and the banned substance can freely circulate, endangering society. On the other hand, false positives indicate the presence of an illegal substance that is not present in the sample. They happen because colors can react with impurities or similar compounds to reveal the presence of a specific class of substances, which may be mistaken for the illicit substance [20,30]. It is worrisome because a person carrying a lawful product can suffer the legal consequences related to the banned substance. A typical example is cocaine, which can be confused with other substances, such as caffeine, lidocaine, and procaine. In contrast, cocaine identification by spot tests can return false positives because it is not frequently sold in the pure form. Given that drug screening aims to identify the substance correctly and to assist in future confirmation, studies are being published to avoid misidentification [35].

Colorimetric tests are primarily used because a chemical reaction yields a color change $[21,36]$. These tests have gained prominence and have been widely applied for traditional substances, as shown in Figure 3, which illustrates an example of a forensic analysis route for an unknown seized substance.

Colorimetric tests do not demonstrate the same effectiveness for NPS: responses can vary according to the NPS concentration in the sample [37]. Besides, a broad spectrum of color responses is possible $[38,39]$ because of the absence of control in NPS production, which can provide reaction residues, which affect the color results $[38,40,41]$. Bearing in mind that instabilities in presumptive test results occur even for well-known traditional substances, NPS analysis poses additional challenges, and uncertainties in NPS color tests require a better presumptive tool. This situation calls for more frequent application of advanced analytical equipment at the apprehension sites. 


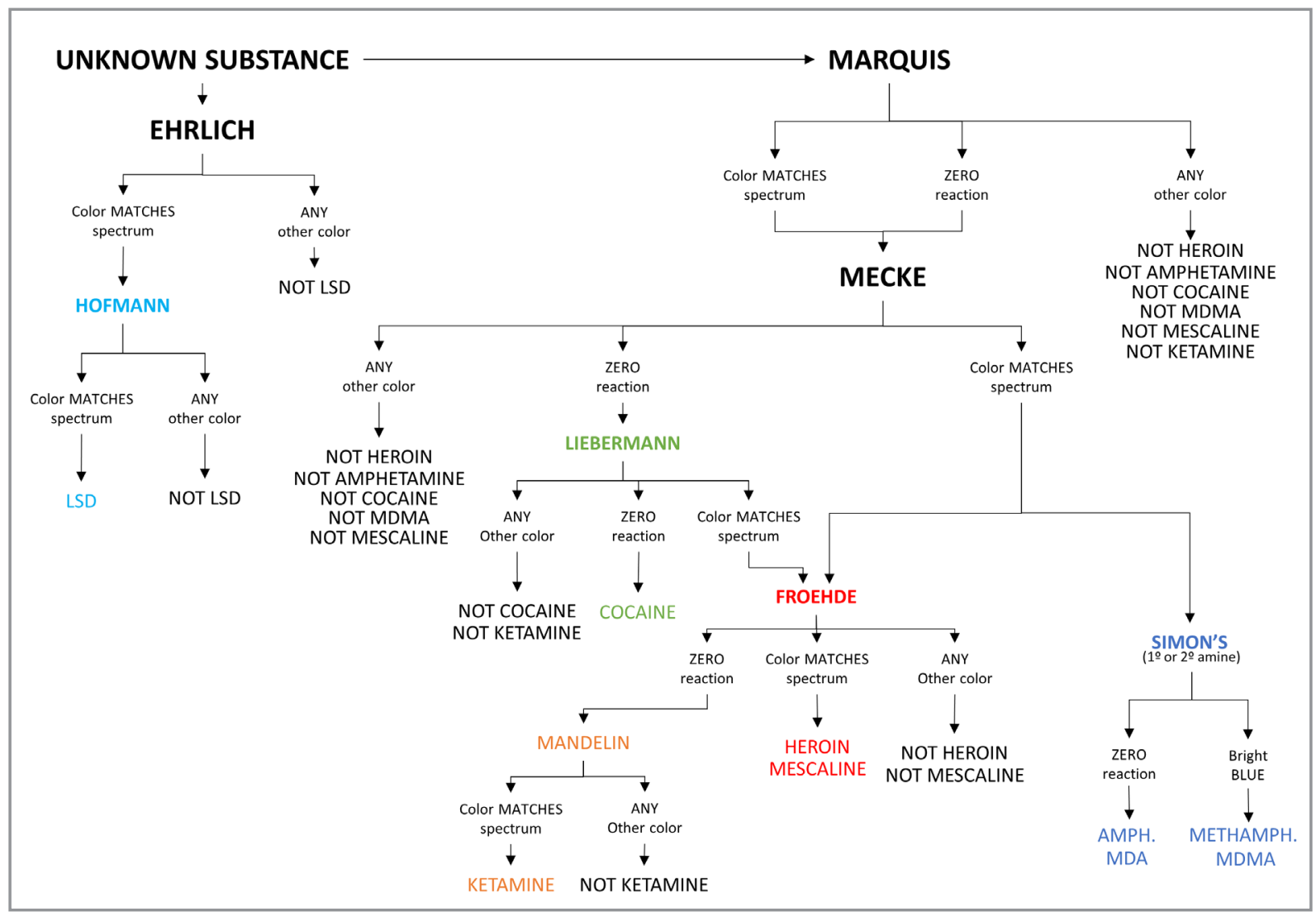

Figure 3. Schematic representation of the use of colorimetric tests as a filter to indicate possible substances $[17,21,38,40,42]$.

\section{Section III: The basics of confirmatory tests}

After a positive presumptive test, the substance structure must be confirmed. In this step, the use of reliable analytical equipment is mandatory.

The Scientific Working Group for the Analysis of Seized Drugs (SWGDRUG) recommendations [43] establishes three categories of techniques grouped according to their highest level of selectivity (see Table I). In each identification category, the techniques are grouped according to the selectivity. For Category A, selectivity is based on structural information. For Category $B$, selectivity is based on chemical and physical characteristics. For Category C, selectivity is based on general or class information. Additionally, the SWGDRUG recommendations state that:

- When a Category A technique is incorporated into an analytical scheme, at least one other technique from Category A, B, or C that explores different chemical or physical properties of the analyte must be used to support identification.

- When a Category A technique is not used, at least three different techniques must be employed; two must be Category B techniques, whose combination should provide a high degree of selectivity. The third technique (Category $\mathrm{B}$ or $\mathrm{C}$ ) is required to support the identification.

For the analyte to be successfully identified, the test results must be positive, meet all quality control requirements, and achieve the required selectivity. The UNODC's Manual for use by National Drug Analysis Laboratories [44] recommends that at least three entirely different analytical techniques (e.g., color tests, chromatography, and spectroscopy) be used. 
Table I. SWGDRUG recommended techniques [43]

\begin{tabular}{|c|c|}
\hline Category & Technique \\
\hline $\begin{array}{c}\text { A } \\
\text { Selectivity based on Structural Information }\end{array}$ & $\begin{array}{l}\text { Infrared Spectroscopy } \\
\text { Mass Spectrometry } \\
\text { Nuclear Magnetic Resonance } \\
\text { Raman Spectroscopy } \\
\text { X-Ray Diffractometry }\end{array}$ \\
\hline $\begin{array}{l}\text { B } \\
\text { Selectivity based on Chemical and Physical } \\
\text { Characteristics }\end{array}$ & $\begin{array}{l}\text { Capillary electrophoresis } \\
\text { Gas chromatography } \\
\text { lon mobility spectrometry } \\
\text { Liquid chromatography } \\
\text { Microcrystalline tests } \\
\text { Pharmaceutical identifiers } \\
\text { Thin layer chromatography }\end{array}$ \\
\hline $\begin{array}{l}\text { Selectivity based on General or Class } \\
\text { Information }\end{array}$ & $\begin{array}{l}\text { Color tests } \\
\text { Fluorescence spectroscopy } \\
\text { Immunoassay } \\
\text { Melting point } \\
\text { Ultraviolet spectroscopy }\end{array}$ \\
\hline
\end{tabular}

There are disadvantages associated with confirmatory tests. Sample preparation can be significant and time-consuming. Besides that, the sample can be destroyed during the testing process, and consumable materials could be required [45-47].

\section{Amphetamine-type stimulants - ATS (amphetamines and cathinones)}

Phenylethylamines (phenylethan-2-amine) correspond to a group of small alkaloids with a basic structure containing a benzene ring and an ethyleneamine carbon chain (Figure 4(a)) [48]. Amphetamines and cathinones are among the molecules that belong to this group. Both structures are known as substituted phenylethylamines. a-Methylphenylethylamine is the simplest amphetamine known to date (Figure 4(b)) [49]; a-aminopropiophenone is a cathinone (Figure 4(c)) [50,51]. Along with synthetic cannabinoids, these two groups are the main classes of substances that have fostered the rapid growth of NPS's worldwide phenomenon [52-55]. Cathinones and amphetamines have similar structures and hence similar stimulating effects [56]. Their effects are comparable to the effects of cocaine on the body [57-59]. Specifically, they act by inhibiting the return of the monoamine transporter proteins from the synaptic cleft to the pre-synaptic neuron [60-62]. Although there are three monoamine transporters serotonin transporter (SERT), dopamine transporter (DAT), and norepinephrine transporter (NET) [63-65] - nonspecific transport between serotonin, dopamine, or norepinephrine and SERT, DAT, or NET has been reported $[66,67]$. Cathinones and amphetamines are divided into classes depending on the carrier they preferentially act $[68,69]$. The stimulating effects are complex but similar to the effects of cocaine $[61,69]$, and they include paranoia reflexes, delirium, tachycardia, hypertension, aggressive behavior, and pulmonary edema $[24,68,70-72]$. 


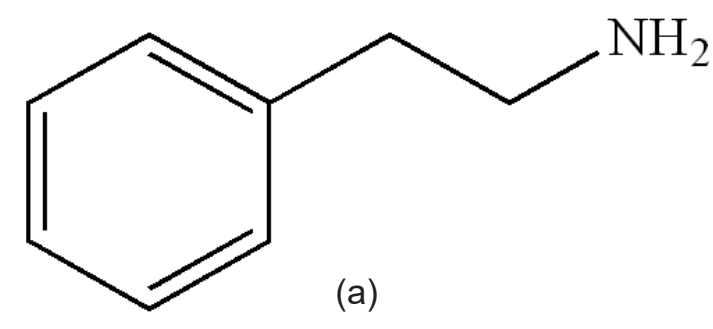

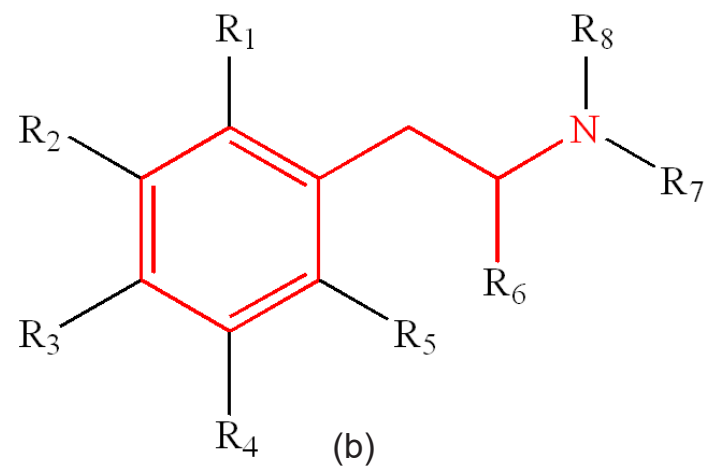

(b)

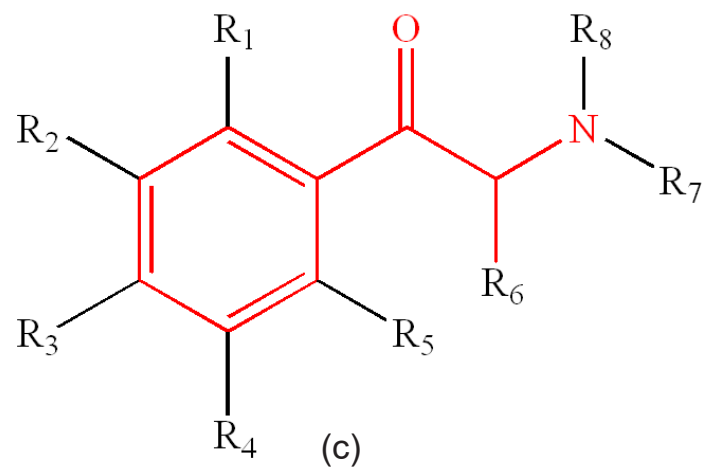

(c)

Figure 4. Schematic representation of the molecular structures of (a) Phenylethylamine, (b) Amphetamine-like substances, and (c) Cathinone-like substances.

Amphetamines and cathinones have a similar chemical structure [73], which is challenging for their characterization and differentiation. When colorimetric tests are used for initial evaluation, detection is not based on structures but on a chemical reaction characteristic of specific functional groups. This reaction causes a certain color to appear when the result is positive. However, false positives and false negatives can occur because there are tests which lack specificity $[74,75]$. For example, the Marquis Test (Color test - Category C) [38] provides a positive response for methylenedioxymethamphetamine (MDMA), fentanyl, and tramadol [40], whose structures belong to different classes of drugs. It is necessary to have specific detectors aligned with NPS demands, minimizing errors in presumptive tests. Possibilities include new molecules for detection [76,77], nanomaterials [78-80], and macromolecules in sensors [81,82].

For amphetamines and cathinones, Category $B$ techniques can chemically differentiate between them due to differences in lipophilicity. The most straightforward structures may not have groups that alter lipophilicity. Differentiation is possible due to the presence of $\beta$-ketone in the cathinone derivatives, making them less lipophilic than amphetamines [4].

Different laboratory techniques can be applied to confirm presumptive tests. Mass spectrometry (MS) [83-86] provides characteristic fragmentations for amphetamines and cathinones. Due to the presence of the $\beta$-keto group in cathinones, chromatographic techniques can identify them [87-91]. Techniques such as nuclear magnetic resonance (NMR) [92-96], spectroscopy in the infrared region (IR) [21,97-99], and X-ray diffraction $[100,101]$, among others [88,102-104], can accurately distinguish between amphetamines and cathinones. From a legal perspective, the technical professional that carries out the analyses must be able to distinguish between these substances because there is no consensus on banning amphetamines and cathinones.

Although validation methodologies are available, detection techniques pose challenges. One of them is that a condition of polysubstance may exist during apprehension. Substances such as caffeine, paracetamol, and methaclopramide, among others, may structurally resemble amphetamines and cathinones. Besides that, degradation products or residues from the synthesis of these substances must be considered [105]. Preparing samples from simple biological material, such as urine and saliva, does not require extensive and complex procedures $[83,89,106,107]$. For more complex biological samples, like blood, meconium, 
or other unconventional matrixes [108-111], preparation requires steps that include the use of liquid or solid extractions $[112,113]$. When the substances are still in their commercial form, in powders or tablets, analysis can be directly performed by spectroscopic techniques or through dissolution for further analysis [114-116]. Despite the constant challenges in analyzing amphetamines and cathinones, techniques have been reported for their identification and characterization, including molecular imprinting extraction [117], analysis of stable isotopes [118], methods based on electrochemical techniques [119-122], nanoparticles or macroparticles [123,124], and miniaturization [125], all of which can be combined with chemometrics [126-129].

\section{Synthetic cannabinoids}

$\triangle 9$-tetrahydrocannabinol ( $T H C$ ) and other cannabinoids are distributed differently in the brain, with high concentrations in the neocortical, limbic, sensory, and motor areas. Cannabis affects almost every system in the body; acts as anxiolytic, sedative, analgesic, and psychedelic agent; stimulates appetite; and has systemic effects [130,131].

THC and other CB1 cannabinoid receptor agonists react to the responses of the central nervous, providing beneficial analgesia, attenuating nausea, and vomiting in cancer chemotherapy, reducing intraocular pressure, stimulating appetite in stressful syndromes, relieving muscle spasms/spasticity in multiple sclerosis, and decreasing intestinal motility. However, undesirable side effects accompany these therapeutic responses, such as changes in cognition and memory, dysphoria/euphoria, and sedation [132-135].

Cannabis impairs cognitive and psychomotor performance. Its effects resemble the effects of alcohol and benzodiazepines and include reaction deceleration, motor incoordination, specific defects in short-term memory, difficulty concentrating, and impairment in complex tasks requiring divided attention. Cannabinoids produce dose-related tachycardia that can reach rates of up to 160 beats/minute or more, but tolerance is developed with chronic use. Chronic marijuana smoking is associated with bronchitis and emphysema. At high doses, the effects can change and (i) lead to recent memory loss and difficulty performing tasks that require mental performance, (ii) cause anxiety, and (iii) trigger or aggravate a psychotic condition [130]. Synthetic cannabinoids comprise different products with chemical structures that resemble the structure of THC (Figure 5), the primary psychoactive principle of natural cannabis. The structural characteristics of synthetic cannabinoids allow them to bind to one of the known cannabinoid receptors, namely CB1 or CB2, present in human cells. The emergence of synthetic cannabinoids such as NPS, sold under names like "Spice" and "K2", was first reported in 2004. Since then, new drugs have been increasingly reported in different parts of the world $[136,137]$. Synthetic cannabinoids encompass various structurally different substances, with the possibility of structural changes, potentially modifying affinity for cannabinoid receptors. In general, they represent a diverse group of potent psychoactive substances that can result in agonistic, inverse agonistic, or antagonistic effects [136].
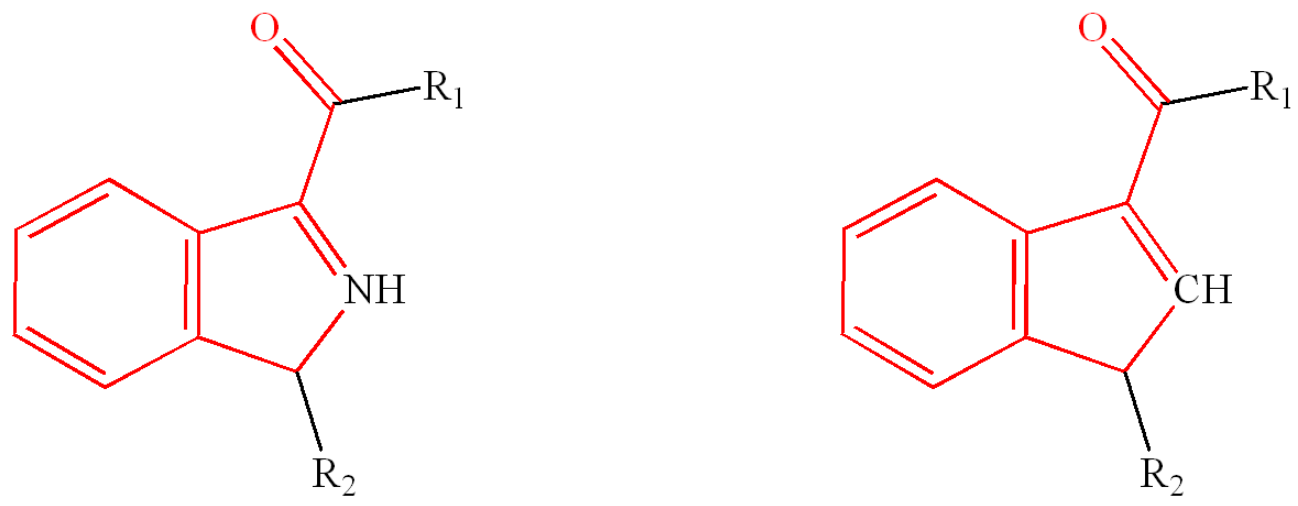

Figure 5. Schematic representation of the molecular structure of synthetic cannabinoid-like substances. 
The large variety of molecular structures poses a challenge for forensic analysis and the identification of synthetic cannabinoids [138]. The most common presumptive tests for Cannabis sativa L. are Fast Blue $B$ (FBB) and Duquenóis-Levine, which are based on the reaction of the analyte with the phenolic groups present in the chemical structure of the FBB and Duquenóis-Levine reagents [139]. The emergence of synthetic cannabinoids has posed significant problems for their presumptive identification by traditional color tests. Despite being marketed and sold as "legal high" products, these substances do not contain the active constituent present in marijuana, THC, so that Duquenóis-Levine test could be inappropriate. Synthetic cannabinoids are a diverse class of NPS that contain different sub-class structures [17]. A specific test for these substances is challenging because analogous compounds present in vegetables can behave similarly [139]. Literature shows studies on tests with synthetic cannabinoids. There have been reported tests for the cannabinoid $\mathrm{JWH}-019$ which provide false positives results [140]. The Fast Blue BB reagent (FBBB) has been studied to test three cannabinoids: THC, cannabidiol (CBD), and cannabinol (CBN). There are commercial teas which have been used for comparison and proven to interfere in the test when extracted with polar solvent [141]. Microcrystal testing is not an alternative for analyzing synthetic cannabinoids, either, because herbal mixtures have low concentrations of analytes. Commercially available tests do not provide satisfactory results for all synthetic cannabinoids $[136,142]$. There are examples of experimental conditions to determine specific synthetic cannabinoids by thin-layer chromatography (TLC) [143].

Color and microcrystal tests are unsuitable for analyzing herbal products due to the low concentration of analytes and possible interferents. In this case, ion mobility spectrometry (IMS) can be considered a sensitive screening method for use as a presumptive test. IMS is a fast and sensitive technique that can detect traces of organic compounds, does not require extraction, and allows easy sampling and handling. The technique can be used as a rapid field detection technique $[30,136]$.

The analytical approach for obtaining information about the chemical structure of synthetic cannabinoids differs from the classic analysis of phytocannabinoids. An essential aspect to consider is sampling: although each product is sold under a specific commercial name, the same group or lot might have different contents. Sensitive methods are necessary to analyze low concentrations of synthetic cannabinoids (usually 1-30 $\mathrm{mg} \mathrm{g}^{-1}$ ), and matrix interference may be possible. Several methods can assist in the analysis: gas chromatography with flame ionization detector (GC-FID), gas chromatography with infrared detector (GC-IRD), gas chromatography with mass detector (GC-MS), TLC, Fourier transform infrared (FTIR), and attenuated total reflectance FTIR (ATR-FTIR) [136].

Simple extraction procedures are crucial for chromatographic analysis because active substances usually adhere to the surface of the plant material. GC-MS analysis can be considered the gold standard because it provides excellent chromatographic resolution. Furthermore, it allows active ingredients to be identified by their spectra with cold electron ionization (GC-MS-EI). However, this technique can be limited when position isomers are analyzed. The analyst should consider performing additional measurements with other IR or GC-IRD techniques to distinguish between them and to provide unambiguous identification $[136,144]$.

Different synthetic cannabinoids exist, so GC-IRD is a valuable tool to identify similar molecules, such as regioisomers, diastereomers, and other isobaric molecules that exhibit almost identical MS spectra.

TLC is a cheap and fast technique that allows large numbers of samples to be processed. When coupled with ambient mass spectrometry techniques, such as Desorption Electrospray Ionization-Mass Spectroscopy (DESI-MS), a wide range of analytes can be identified [145].

In general, an extraction step allows a good IR spectrum to be obtained by evaporating the extract directly into the ATR diamond cell. Mobile FTIR systems are also helpful for fast sorting of materials seized in the field [146].

For quantitative analyses, techniques such as GC-FID, ultra-high performance liquid chromatography (UHPLC), and liquid chromatography coupled to mass spectrometry (LC-MS/MS) can be used [136]. GC-FID can be employed for both qualitative and quantitative determinations. For samples with very 
low concentrations of the analyte, a more sensitive technique, such as liquid chromatographic methods, should be used. This is because there are fatty acid derivatives can interfere in gas chromatography methods. LC-MS/MS is suitable for analyses of low concentrations of synthetic cannabinoids in complex herbal mixtures. Its low detection limits allow tracking and analysis of biological specimens, such as blood and hair $[147,148]$.

Other techniques and approaches can be applied to analyze synthetic cannabinoids in herbal products [136]. Direct analysis in real-time mass spectrometry (DART-MS) or desorption atmospheric pressure photoionization (DAPPI) can be directly used in plant material, without the need for extraction or sample preparation [149,150]. High-resolution mass spectrometry (HRMS) can be used to determine the precise elementary compositions of new synthetic molecules, double bonds, and precise mass of ions/fragment [151]. Matrix-assisted laser desorption/ionization mass spectrometry (MALDI-TOF-MS) enables direct qualitative analysis of herbal mixtures, offers fast and straightforward operation, provides high analysis performance, and can be used for initial "screening" of confiscated material [152]. As for NMR, it allows the structure of new unknown synthetic cannabinoids to be identified and elucidated [153].

\section{NBOMes}

NBOMes appeared in 2013 and were initially sold on the Internet as a legal alternative to LSD. They are known as N-Bomb, Smiles, Pandora, and Dime. Increased consumption of these substances can be attributed to their low price and wide availability, and they can be sold as powder, pills, ampoules, and stamps. They are usually associated with intoxication and even death and have no reported therapeutic use or adverse effects. This group consists of class $2 \mathrm{C}$ hallucinogens; more specifically, phenethylamines (Figure 6). Despite their structural diversity, one of the most common NBOMes belong to the 25C-NBOMe group [154-157].

The "2C" indication describes the chemical structure in which the phenylamino group is separated by two carbon atoms. The appearance of NBOMes in the underground drug market was favored by the fact that $2 \mathrm{C}$ substances contain substituents such as $\mathrm{N}$-(2-methoxybenzyl) phenethylamines. NBOMes are classified according to their substitution in the $4^{\text {th }}$ position of the dimethoxy phenyl ring, to give substances like 25I-NBOMe (lodine), 25B-NBOMe (Bromine), 25C-NBOMe (Chlorine), and 25H-NBOMe (Hydrogen) and organic groups such as 25D-NBOMe (Methyl), 25E-NBOMe (Ethyl), and 25N-NBOMe (nitro). A "complexant" called hydroxypropyl-b-cyclodextrin can be added to NBOMes during manufacture to make these substances cross membranes more easily, which potentializes their effects. Studies on the activity of NBOMe structures have indicated that the 5-HT2A receptor significantly increases the activity of these substances and hence their pharmacological action. Their hallucinogenic effect stems from activation of these receptors (which imply the same pathophysiology of depression and schizophrenia) given that $\mathrm{N}$-benzyl derivatives have a greater affinity for receptors than analogous " $2 \mathrm{C}$ " substances. Like lysergic acid, NBOMes are active in minimal doses, so they are often sold as an alternative to LSD $[4,156,158-$ 160]. Because NBOMes are new, there is a lack of information about their toxicological properties. They were prohibited only a short time ago. 


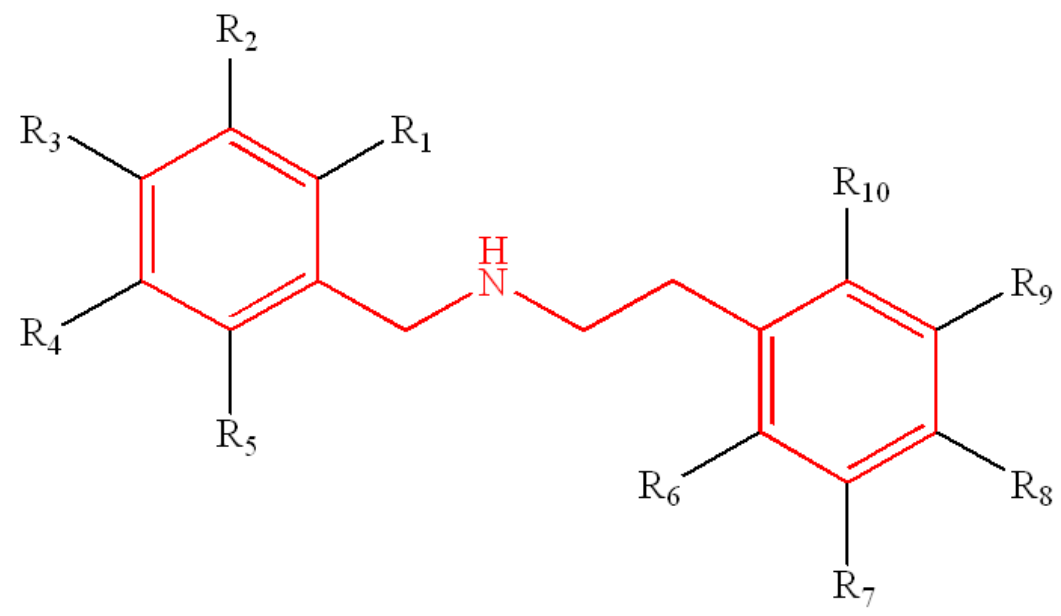

Figure 6. Schematic representation of the molecular structure of NBOMe-like substances.

One of the presumptive tests for detection of NBOMes is the Marquis reagent. This reagent consists of a mixture of $37 \%$ formaldehyde and glacial acetic acid, and drops of sulfuric acid [161]. In contact with NBOMe samples, the reagent may reveal different colors. According to the PRO Test 2021 color chart from Chemical Safety, the colors are as follows: orange for 25C-NBOMe, 25D-NBOMe, 25G-NBOMe, and 25T-NBOMe; greenish for 25B-NBOMe; pink for 25E-NBOMe; reddish-brown for 25IP-NBOMe and $25 \mathrm{~N}-\mathrm{NBOMe}$; and brown for 25H-NBOMe and 25I-NBOMe. The Mecke test, which consists of adding selenous acid to sulfuric acid, can also be used [161]. According to the same color table mentioned previously, the revealed colors are green for 25E-NBOMe and 25IP-NBOMe, dark brown for 25I-NBOMe and 25N-NBOMe, greenish yellow for 25D-NBOMe, dark green for 25H-NBOMe, and lilac for 25T-NBOMe. Bearing in mind that the Marquis test is also used to detect MDMA and amphetamines and can react with common substances such as sugars, false positives can occur because the same colors that would correspond to a specific NBOMe can be revealed when in fact other substances are present in the sample.

The most recommended confirmatory tests to detect and to quantify NBOMe derivatives are liquid and gas mass spectrometry, high-performance liquid chromatography (HPLC), and FTIR. Analysis of NBOMes on blotter papers usually does not require sample preparation when infrared methods are employed. This analysis is non-destructive and preserves the characteristics of the sample, being interesting for forensic objectives. As for liquid chromatography, electroanalytical, and gas chromatography methods, they demand organic solvent extraction, usually methanol. Analysis of biological samples, like blood, urine, serum, vitreous humor, liver, and gastric content, requires extraction with organic solvent for most techniques [162-166]. In samples seized on stamps, GC-MS or LC-MS/MS are generally used. Spectrometric techniques are advantageous: they are not destructive, so the samples are preserved after analysis. Another advantage of these confirmatory tests is the possibility of quantifying and verifying possible impurities. Despite the reliability of these tests, special attention is still needed in the case of GCMS. Depending on sample preparation, it can be confusing for $2 \mathrm{C}$ molecules. These confirmatory tests are mainly applied for seized and biological samples such as fluids and tissues [167-169].

\section{Synthetic opioids}

Opioids and opiates are different. Opiates are alkaloids directly isolated from opium, an extract from poppy (Papaver somniferum), a plant with medicinal properties. Morphine, codeine, and thebaine are prominent examples of opiates. Chemical modifications to these opiates afford semi-synthetic opioids. Heroin is the most remarkable example of this class - it is obtained by deacetylation of morphine. In turn, synthetic opioids are entirely produced in the laboratory, and they simulate pharmacophoric groups of morphine. All these substances have agonist activity at opioid receptors and present similar mechanisms of action, symptoms, and effects, but potency, time, and duration of action are different [170]. 
New Synthetic Opioids (NSO) started to appear in 2010. In 2013, they became a serious public health issue, starting the so-called opioid epidemic in the United States of America (USA) and the European Union (EU). NSO can be divided into fentanyl analogous substances and non-fentanyl-related substances. Fentanyl analogous substances (Figure 7(a)) are known as Nonpharmaceutical Fentanyl (NPF) and include substances of the class 4-anilidopiperidine, which have been synthesized clandestinely or have not been approved for medical use. In addition to fentanyl itself, the main fentanyl analogous substances include carfentanyl, 3-methylfentanyl, alfentanil, acetylfentanyl, butyrfentanyl, furanylfentanyl, and $p$-fluorofentanyl, among others. Non-fentanyl-related substances are less varied and do not belong to a single structural class. Their terminology is linked to the pharmaceutical industry or to the researcher who synthesized it. The main examples of these substances are U-47700, U-50488, AH-7921, MT-45, and fenampromide (Figure 7(b)-(e)) [171,172].

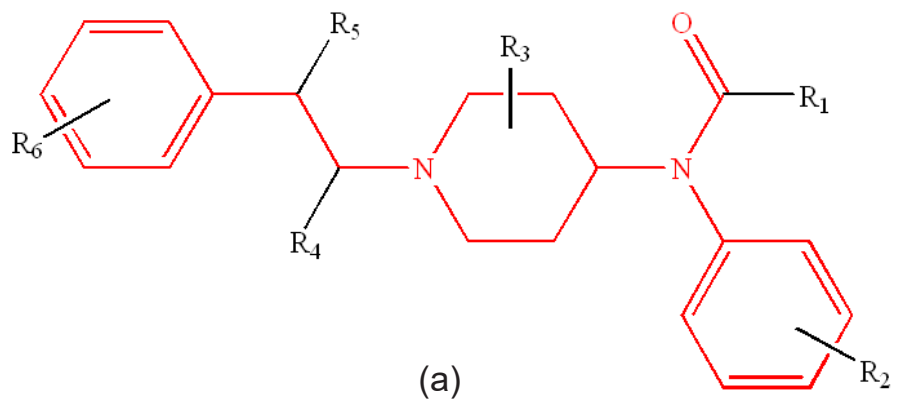<smiles>CN(C(=O)Cc1ccc(Cl)c(Cl)c1)[C@@H]1CCCC[C@H]1N1CCCC1</smiles>

(b)

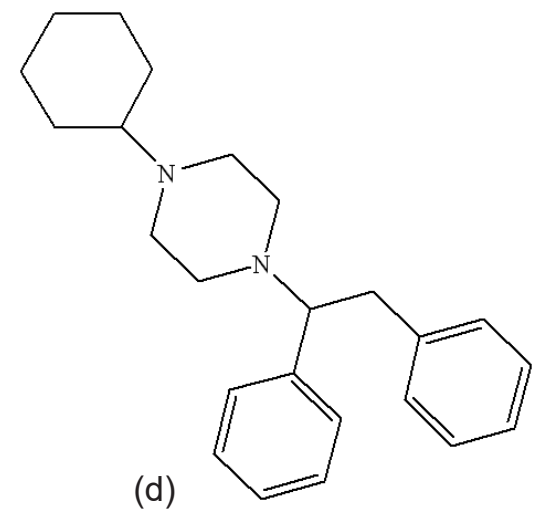<smiles>CN(C)C1(CNC(=O)c2ccc(Cl)c(Cl)c2)CCCCC1</smiles>

(c)<smiles>CCC(=O)N(c1ccccc1)C(C)CN1CCCCC1</smiles>

(e)

Figure 7. Schematic representation of the molecular structure of (a) Fentanyl-like substances, (b) U-50488, (c) AH-7921, (d) MT-45, and (e) Fenampromide. 
The most used technique for detection of synthetic opioids is chromatography; more specifically, GC-MS and LC-MS/MS and liquid chromatography coupled to high-resolution mass spectrometry (LCHRMS) [173-175]. High-performance liquid chromatography coupled to ultraviolet detector (HPLC-UV) or amperometric detector (HPLC-AD) [176], ultra-performance liquid chromatography coupled to mass spectrometry (UPLC-MS/MS) [177], and ultra-high performance liquid chromatography coupled to mass spectrometry (UHPLC-MS /MS) are also used [178]. Other techniques include IMS and direct analysis of thermal desorption in real-time mass spectrometry (TD-DART-MS) [179], Raman and Infrared spectroscopy [180], and NMR [181].

Analyzed matrixes include blood (whole blood, serum, and plasma), urine, liver, bile, vitreous humor, brain, gastric tissue, kidney, seized samples, and sewage. As for extraction techniques, dilution, liquidliquid extraction (LLE), solid-phase extraction (SPE), and protein precipitation (PP) are generally used $[88,173]$.

The presumptive tests that are most used to detect synthetic opioids are colorimetric tests, thin-layer chromatography, strip tests, and immunoassays [21]. Among the colorimetric tests, the commercially available Marquis test and Scott test stand out, as well as the Eosin $Y$ test, which is not yet commercially available. These three tests provide adequate results for the presumptive detection of 18 fentanyl analogs. The fentanyl analogs react with the Marquis reagent, to form an orange color immediately and a dark brown color after five minutes. MDMA, heroin, codeine, and morphine also respond to the Marquis reagent, albeit with different colors. The Scott reagent reacts with the fentanyl analogs, benzocaine, and cocaine, to form a blue tint. The Eosin Y reagent reacts with the fentanyl analogs, to give a dark pink color, and with benzocaine, procaine, caffeine, acetaminophen, cocaine, codeine, morphine, and heroin, to result in a light pink color. The discriminating ability of $\mathrm{TLC}\left(\mathrm{SiO}_{2}\right.$, chloroform-benzene-methanol $\left.(10: 2: 1 \mathrm{v} / \mathrm{v} / \mathrm{v})\right)$ has been tested for fentanyl, 4-ANPP, and heroin analogs. TLC can detect the analytes with the modified DragendorffLudy-Tenger reagent, and their retention factors ( $\mathrm{Rf}$ ) have been recorded. Although discrimination of all the 18 fentanyl analogs is not entirely possible, discriminating the fentanyl analogs from N-phenyl-1-(2phenylethyl)-4-piperidinamine (4-ANPP) and heroin is feasible under these conditions [88].

Immunoassay-based strip tests have been tested for 28 fentanyl analogs. The selectivity and sensitivity of the tests allow between 21 and 24 analogs to be detected. The tests depend entirely on the concentration of the drug solution [182]. Evaluation of immunoassay-based tests has shown that they can detect 11 fentanyl analogs [183]. Immunoassays for opioids use mainly morphine to indicate the result, which can make detection difficult when various drugs are present in the seized sample, making identification impossible [33].

\section{Benzodiazepines}

Benzodiazepines, or benzos, are central nervous system depressants with a fused benzene and a diazepine ring system [184]. Figure 8 shows their basic chemical structure. They are classified as sedativehypnotic medications. They have been prescribed since the late 1960s in the United States because they are highly effective for several medical disorders and short-term treatment of mental health disorders such as anxiety, insomnia, and panic disorder, with the advantage that they are safer than other drugs, especially barbiturates [184-189]. The most common benzodiazepines are diazepam (Valium), lorazepam, and alprazolam, and their abuse has been discussed by Cole and Chiarello [185]. 


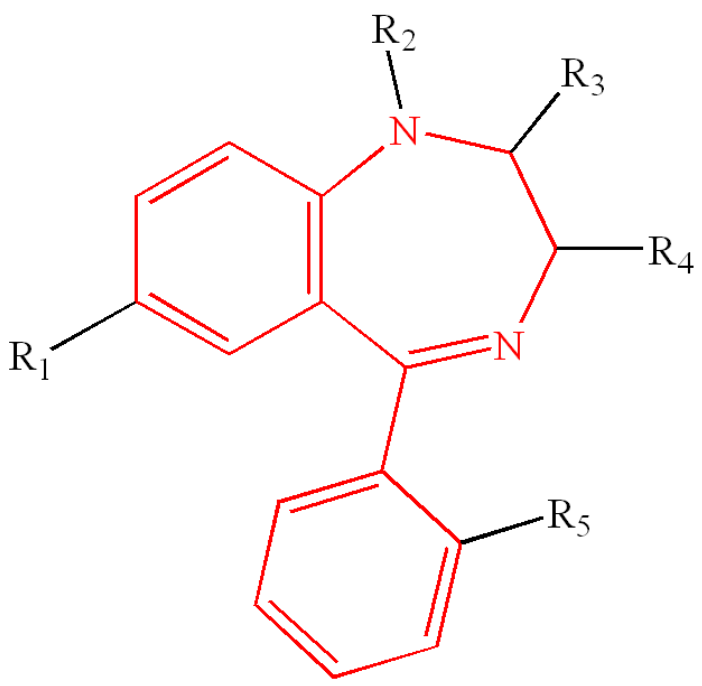

Figure 8. The classical structure of benzodiazepines is based on a 5-aryl-1,4benzodiazepine structure. "R" labels denote common locations of side chains, which give different benzodiazepines their unique properties [44].

The abuse potential of benzodiazepines was recognized as soon as they started being prescribed, which led the United Nations Convention on Psychotropic Substances 1971 to place 38 benzodiazepines under control $[54,190]$. Benzodiazepines are one of the most prescribed drugs in the world. They have been linked to a relevant number of deaths. Indeed, many people who were prescribed these drugs for legitimate medical treatment became addicted to them and developed abusive behavior. In the United Kingdom (UK), 21 million benzodiazepine prescriptions take place every year, and 1.5 million people are estimated to be addicted to them [188,191,192].

The abuse of benzodiazepines is a global issue, and an increasing number of NPS-benzodiazepines have appeared in various countries [186,187,193,194]. Elliot and Evans [186] reported that benzodiazepines were present in 38 of 203 cases related to NPS between 2010 and 2012. By 2013, new benzodiazepines such as etizolam and flubromazepam had emerged. Benzodiazepine abuse was reported to have contributed to $45 \%$ of the opioid-induced deaths in Australia in 2016. Furthermore, in 2017, sedative hypnotic substances represented $33 \%$ of the overall NPS reported to UNODC for the first time at global level [195].

Manchester et al. [190] mentioned the emergence of NPS-benzodiazepines in many countries all over Europe. Several of these substances have never undergone the clinical testing that is required of licensed medicines, so their increasing availability poses serious health risks to polydrug users and benzodiazepinedependent patients who can no longer obtain their prescription and may turn to other means of obtaining benzodiazepines.

In the case of benzodiazepines, which are usually supplied as tablets, capsules, or liquids to be injected, the presumptive test is the Zimmerman test $[18,44]$. This test is not specific for benzodiazepines, so analysts are advised to combine TLC and cooler development after spraying with selected reagents as a presumptive test. In seized samples, benzodiazepines are commonly present as the free base, hydrochloride, mesylate, or salt.

TLC is a technique that gives good separations for several benzodiazepines. Different preparation methods and visualization are prescribed, and results have been reported for three solvent systems [44].

A colorimetric test based on cobalt thiocyanate has been developed for presumptive identification of benzodiazepines. Such test can be used to quantify these substances and has the advantage of being rapid, highly specific, and low-cost. This color test produces green color for eight benzodiazepines - nitrazepam, temazepam, diazepam, bromazepam, clonazepam, estazolam, lormetazolam, and alprazolam, whereas developed color was absent in other controlled or pharmaceutical substances tested during the study. 
Therefore, this test can be a helpful presumptive screening tool for benzodiazepines in suspected illicit samples and pharmaceuticals [196].

GC-FID can analyze most benzodiazepines. However, many of these substances may undergo thermal degradation. GC-MS provides precise spectral data for individual analytes in complex mixtures, often without prior separation. HPLC presents limitations regarding compound separation with benzodiazepines. However, there are recommended methods for qualitative and quantitative analysis of the substances under international control. LC-MS/MS represents a rapid, simple, and overly sensitive procedure for simultaneous analysis of fourteen benzodiazepines. IR usually provides unequivocal identification of benzodiazepines. Still, there are cases of poor solubility in chloroform samples, so the drug cannot be separated in its pure form, which is a limitation of this method and requires other preparation methods [44].

Analytical methods for determining benzodiazepines in human biological specimens have also been reported [190,197,198].

\section{CONCLUSION}

Correct identification of illicit substances is essential for law enforcement and health care and driving justice and public policies. Although drug testing is routine in Forensic Laboratories, new analytical challenges have emerged with the rise of new psychoactive substances. Even though various methodologies can be used for drug identification, there is no specific testing methodology for NPS.

In the case of presumptive tests, joint problems and pitfalls include the fact that these tests cannot differentiate numerous compounds that are prohibited. The alternative would be using portable spectroscopic equipment to increase reliability. However, such equipment is expensive and inaccessible to investigative bodies. On the other hand, reliable confirmatory tests are costly and require special conditions for analysis. They can require extensive sample preparation and may be destructive. One of the significant challenges is obtaining analytical standards that can serve as a reference. Even though these tests are reliable, the lack of analytical standards does not allow correct definitive identification. Furthermore, analysis is subject to the analyst's interpretations, which can be subjective. Even when resources for confirmatory tests are available, they may not be sufficient to provide accurate information, thus limiting correct identification [199].

In this paper, we have provided an overview of five classes of compounds. We have presented characteristics and made comments regarding their testing. Information about these drugs is widespread in the literature. It is essential to highlight that there is no ideal method for NPS identification. Combining different analytical tools might be necessary when evaluating these substances. Besides that, new analytical approaches can be constantly searched to improve detection and identification $[28,138,200]$.

There is a constant demand for new information about the chemical characteristics and effects of these substances. Concrete data on seizures, quantity, and types of substances are essential to feed collaborative actions in law enforcement, regulation control, and harm reduction and help set drug policies.

\section{Conflicts of interest}

The authors declare no conflict of interest.

\section{Acknowledgment}

The authors thank the Brazilian Agencies: Conselho Nacional de Desenvolvimento Científico e Tecnológico (CNPq, Grant 465450/2014-8), Coordenação de Aperfeiçoamento de Pessoal de Nível Superior - Brasil (CAPES) - Finance Code 001. We also thank Cynthia Maria de Campos Prado Manso for language editing and proofreading. 


\section{REFERENCES}

1. https://www.globalcommissionondrugs.org/wp-content/uploads/2020/06/2020report_EN_ web_100620.pdf [Accessed 9 July 2021].

2. https://www.marshallcenter.org/en/publications/occasional-papers/new-psychoactive-substanceschallenges-law-enforcement-agencies-and-law [Accessed 9 July 2021].

3. Gomes-Medeiros, D.; Faria, P. H.; Campos, G. W. S.; Tófoli, L. F.; Tófoli, C. L. Cad. Saúde Pública, 2019, 35 (7), 242618 (https://doi.org/10.1590/0102-311X00242618).

4. Zawilska, J. B.; Kacela, M.; Adamowicz, P. Front. Neurosci., 2020, 14, p 78 (https://doi.org/10.3389/ fnins.2020.00078).

5. Korf, D.; Benschop, A.; Werse, B.; Kamphausen, G.; Felvinczi, K.; Dabrowska, K.; Hernriques, S.; Nabben, T.; Wieczorek, L.; Bujalski, M.; et al. Int. J. Ment. Health Addict., 2021, 19, pp 873-890 (https://doi.org/10.1007/s11469-019-0052-8).

6. Liu, L.; Wheeler, S. E.; Venkataramanan, R.; Rymer, J. A.; Pizon, A. F.; Lynch, M. J.; Tamama, K. Am. J. Clin. Pathol., 2018, 149 (2), pp 105-116 (https://doi.org/10.1093/AJCP/AQX138).

7. https://assets.publishing.service.gov.uk/government/uploads/system/uploads/attachment_data/ file/368583/NPSexpertReviewPanelReport.pdf [Accessed 22 March 2021].

8. https://www.gov.br/anvisa/pt-br/assuntos/medicamentos/controlados/lista-substancias [Accessed 09 September 2021].

9. https://www.in.gov.br/en/web/dou/-/resolucao-rdc-n-372-de-15-de-abril-de-2020-252726528 [Accessed 09 September 2021].

10. http://www.globalcommissionondrugs.org/wp-content/uploads/2018/09/ENG-2018_Regulation_ Report_WEB-FINAL.pdf [Accessed 9 July 2021].

11. Kurcevič, E.; Lines, R. Harm Reduct. J., 2020, 17, Article number 94 (https://doi.org/10.1186/s12954020-00448-2).

12. http://www.globalcommissionondrugs.org/wp-content/uploads/2019/06/2019Report_POR_web.pdf [Accessed 09 September 2021].

13. Nutt, D. J.; King, L. A.; Phillips, L. D. Lancet, 2010, 376 (9752), pp 1558-1565 (https://doi. org/10.1016/S0140-6736(10)61462-6).

14. Peacock, A.; Bruno, R.; Gisev, N.; Degenhardt, L.; Hall, W.; Sedefov, R.; White, J.; Thomas, K. V; Farrell, M. Lancet, 2019, 394 (10209), pp 1668-1684 (https://doi.org/10.1016/S01406736(19)32231-7).

15. Steuer, A. E.; Brockbals, L.; Kraemer, T. Front. Chem., 2019, 7, p 319 (https://doi.org/10.3389/ fchem.2019.00319).

16. Gerostamoulos, D.; Elliott, S.; Walls, H. C.; Peters, F. T.; Lynch, M.; Drummer, O. H. J. Anal. Toxicol., 2016, 40 (4), pp 318-320 (https://doi.org/10.1093/jat/bkw013).

17. Philp, M.; Fu, S. Drug Test. Anal., 2018, 10 (1), pp 95-108 (https://doi.org/10.1002/dta.2300).

18. Wolstenholme, R.; Jickells, S.; Forbes, S. (Eds.) Analytical Techniques in Forensic Science, $1^{\text {st }}$ ed., Wiley, Chichester, UK, 2021.

19. Clancy, L.; Philp, M.; Shimmon, R.; Fu, S. Drug Test. Anal., 2020, 13 (5), pp 929-943 (https://doi. org/10.1002/dta.2905).

20. Maskell, P. D.; Jackson, G. WIREs Forensic Sci., 2020 (https://doi.org/10.1002/wfs2.1371).

21. Harper, L.; Powell, J.; Pijl, E. M. Harm Reduct. J., 2017, 14, Article number 52 (https://doi.org/10.1186/ s12954-017-0179-5).

22. Zhao, L.; Wang, P. Arch. Pathol. Lab. Med., 2020, 144 (11), pp 1325-1334 (https://doi.org/10.5858/ arpa.2020-0055-RA).

23. Penido, C. A. F. O.; Pacheco, M. T. T.; Lednev, I. K.; Silveira, L. J. Raman Spectrosc., 2016, 47, pp 28-38 (https://doi.org/10.1002/jrs.4864).

24. Hondebrink, L.; Nugteren-van Lonkhuyzen, J. J.; Van Der Gouwe, D.; Brunt, T. M. Drug Alcohol Depend., 2015, 147, pp 109-115 (https://doi.org/10.1016/j.drugalcdep.2014.11.033). 
25. United Nations Office on Drugs and Crime. Recommended methods for the Identification and Analysis of Synthetic Cathinones in Seized Materials (Revised and updated). United Nations Publication, Vienna, 2020.

26. Bulska, E.; Bachliński, R.; Cyrański, M. K.; Michalska-Kacymirow, M.; Kośnik, W.; Małecki, P.; Grela, K.; Dobrowolski, M. A. Front. Chem., 2020, 8, p 693 (https://doi.org/10.3389/fchem.2020.00693).

27. dos Santos, P. F.; Souza, L. M.; Merlo, B. B.; Costa, H. B.; Tose, L. V.; Santos, H.; Vanini, G.; Machado, L. F.; Ortiz, R. S.; Limberger, R. P.; et al. Quim. Nova, 2015, 39 (2), pp 229-237 (https:// doi.org/10.5935/0100-4042.20150178).

28. Shafi, A.; Berry, A. J.; Sumnall, H.; Wood, D. M.; Tracy, D. K. Ther. Adv. Psychopharmacol., 2020, 10 (https://doi.org/10.1177/2045125320967197).

29. United Nations Office on Drugs and Crime. World Drug Report 2013. United Nations Publication, Sales No. E.13.XI.6: Vienna, 2013.

30. Snyder, C. Developing a Presumptive Test for Select Synthetic Cannabinoids. Master thesis, 2013, University of Arkansas, Fayetteville, United States.

31. Tadini, M. C.; Balbino, M. A.; Eleoterio, I. C.; De Oliveira, L. S.; Dias, L. G.; Jean-franc, G.; De Oliveira, M. F. Electrochimica Acta, 2014, 121, pp 188-193 (https://doi.org/10.1016/j.electacta.2013.12.107).

32. Freitas, J. M.; Ramos, D. L. O.; Sousa, R. M. F.; Paixão, T. R. L. C.; Santana, M. H. P.; Muñoz, R. A. A.; Richter, E. M. Sensors Actuators B. Chem., 2017, 243, pp 557-565 (https://doi.org/10.1016/j. snb.2016.12.024).

33. Milone, M. C. J. Med. Toxicol., 2012, 8, pp 408-416 (https://doi.org/10.1007/s13181-012-0274-7).

34. Grafinger, K. E.; Liechti, M. E.; Liakoni, E. Br. J. Clin. Pharmacol., 2020, 86 (3), pp 429-436 (https:// doi.org/10.1111/bcp.14115).

35. Marcelo, M. C. A.; Mariotti, K. C.; Ortiz, R. S.; Ferrão, M. F.; Anzanello, M. J. Microchem. J., 2016, 127, pp 87-93 (https://doi.org/10.1016/j.microc.2016.02.012).

36. Toole, K.; Philp, M.; Krayem, N.; Fu, S.; Shimmon, R.; Taflaga, S. In: Musah, R. A., Ed. Analysis of Drugs of Abuse. Humana Press, New York, NY, 2018, pp 1-11.

37. Philp, M.; Shimmon, R.; Stojanovska, N.; Tahtouh, M.; Fu, S. Anal. Methods, 2013, 5, pp 5402-5410 (https://doi.org/10.1039/c3ay40511g).

38. Darsigny, C.; Couture, M. L.; Desgagné-Penix, I. Austin J. Forensic Sci. Criminol., 2018, 5 (1), id1074.

39. Toole, K. E.; Fu, S.; Shimmon, R. G.; Kraymen, N.; Taflaga, S. Microgram J., 2012, 9, pp 27-32.

40. Hafer, K. E.; Brettell, T. A. In: Encyclopedia of Analytical Chemistry, John Wiley \& Sons, Ltd. Chichester, UK, 2018, pp 1-18.

41. Tsumura, Y.; Mitome, T.; Kimoto, S. Forensic Sci. Int., 2005, 155 (2-3), pp 158-164 (https://doi. org/10.1016/j.forsciint.2004.11.011).

42. https://bunkpolice.com/ [Accessed 22 March 2021].

43. https://www.swgdrug.org/Documents/Comment\%20Adjudication\%20for\%20IIIB.pdf [Accessed 09 September 2021].

44. Gray, A.; Tettey, J.; Lillisunde, P.; Naidia, I. Recommended methods for the Identification and Analysis of Barbiturates and Benzodiazepines under International Control. United Nations of Drugs and Crime, New York, 2012, pp 1-78.

45. Shergill, A.; Zahid, S.; Bauman, I. In: Clayton, M.; Abbas, N. (Eds.) Voices of Forensic Science: Are We There Yet? The Golden Standards of Forensic Science. Forensic Science Program, University of Toronto Mississauga, Mississauga, ON, Canada, 2021, pp 213-230.

46. Hulme, M. C. New Psychoactive Substances - New Analytical Challenges and Approaches. Doctoral thesis, 2018, Department of Natural Sciences, Manchester Metropolitan University.

47. Klingberg, J. C. Detection and Profiling of Synthetic Opioids Certificate of authorship and originality. Doctoral thesis, 2021, University of Technology Sydney, Australia.

48. Kelly, J. P. Drug Test. Anal., 2011, 3 (7-8), pp 439-453 (https://doi.org/10.1002/dta.313). 
49. Cipriano, P. A. D. Fenetilaminas: De Drogas de Abuso ao Uso Medicinal - Síntese, Propriedades Farmacológicas e Toxicológicas, Monography (Chemistry), 2018, University Federal of São João del-Rei, São João del-Rei, MG, Brazil.

50. Berrang, B. D.; Lewin, A. H.; Carroll, F. I. J. Org. Chem., 1982, 47 (13), pp 2643-2647 (https://doi. org/10.1021/jo00134a026).

51. Gussow, L. Emerg. Med. News., 2015, 37 (11), p 24 (https://doi.org/10.1097/01. EEM.0000473176.23346.fc).

52. United Nations Office on Drugs and Crime. Market Analysis of Synthetic Drugs. Amphetamine-type stimulants, new psychoactive substances. World Drug Report, United Nations Publication, Sales No. E.17.XI.6: Vienna, Austria, 2017.

53. Feng, L.-Y.; Battulga, A.; Han, E.; Chung, H.; Li, J.-H. J. Food Drug Anal., 2017, 25 (3), pp 461-471 (https://doi.org/10.1016/j.jfda.2017.04.001).

54. United Nations Office on Drugs and Crime. Current NPS Threats, Volume III, $1^{\text {st }}$ ed. United Nations Publication. Vienna, 2020, pp 1-6.

55. United Nations Office on Drugs and Crime. Cross-cutting issues: evolving trends and new challenges. World Drug Report. United Nations Publication, Sales No. E.20.XI.6. Vienna, 2020.

56. Tortajada, R. E.; San Miguel, J. P.; Doménech, M. G.; Oltra-Cucarella, J.; Costa, M. A. Rev. Esp. Drog., 2015, 40, 56.

57. Coppola, M.; Mondola, R. Toxicol. Lett., 2012, 211 (2), pp 144-149 (https://doi.org/10.1016/j. toxlet.2012.03.009).

58. Aarde, S. M.; Creehan, K. M.; Vandewater, S. A.; Dickerson, T. J.; Taffe, M. A. Psychopharmacology (Berl), 2015, 232, pp 3045-3055 (https://doi.org/10.1007/s00213-015-3944-8).

59. Carboni, E.; Spielewoy, C.; Vacca, C.; Nosten-Bertrand, M.; Giros, B.; Di Chiara, G. J. Neurosci., 2001, 21 (9), RC141 (https://doi.org/10.1523/JNEUROSCI.21-09-j0001.2001).

60. Iversen, L.; White, M.; Treble, R. Neuropharmacology, 2014, 87, pp 59-65 (https://doi.org/10.1016/j. neuropharm.2014.01.015).

61. Rickli, A.; Hoener, M. C.; Liechti, M. E. Eur. Neuropsychopharmacology, 2015, 25 (3), pp 365-376 (https://doi.org/10.1016/j.euroneuro.2014.12.012).

62. Wang, K. H.; Penmatsa, A.; Gouaux, E. Nature, 2015, 521, pp 322-327 (https://doi.org/10.1038/ nature14431).

63. O'Brien, C. P. In: Brunton, L. L.; Lazo, J. S.; Parker, K. L. (Eds.) Goodman \& Gilman's: The Pharmacological Basis of Therapeutics, McGraw-Hill Professional, 2009, pp 607-627.

64. Simmler, L. D.; Buser, T. A.; Donzelli, M.; Schramm, Y.; Dieu, L.-H. H.; Huwyler, J.; Chaboz, S.; Hoener, M. C.; Liechti, M. E. Br. J. Pharmacol., 2013, 168 (2), pp 458-470 (https://doi.org/10.1111/ j.1476-5381.2012.02145.x).

65. Schmitt, K. C.; Reith, M. E. A. Ann. N. Y. Acad. Sci., 2010, 1187 (1), pp 316-340 (https://doi. org/10.1111/j.1749-6632.2009.05148.x).

66. Mayer, F. P.; Wimmer, L.; Dillon-Carter, O.; Partilla, J. S.; Burchardt, N. V.; Mihovilovic, M. D.; Baumann, M. H.; Sitte, H. H. Br. J. Pharmacol., 2016, 173 (17), pp 2657-2668 (https://doi.org/10.1111/ bph.13547).

67. DeLarge, A. F.; Erwin, L. L.; Winsauer, P. J. Neuropharmacology, 2017, 119, pp 62-75 (https://doi. org/10.1016/j.neuropharm.2017.04.006).

68. Potocka-Banaś, B.; Janus, T.; Majdanik, S.; Banaś, T.; Dembińska, T.; Borowiak, K. J. Forensic Sci., 2017, 62 (2), pp 553-556 (https://doi.org/10.1111/1556-4029.13326).

69. Lopez-Rodriguez, A. B.; Viveros, M. P. Psychopharmacology (Berl), 2019, 236, pp 1001-1014 (https:// doi.org/10.1007/s00213-019-05213-3).

70. Castellanos, D.; Menendez, B.; Logan, B. K.; Mohr, A. L. A.; Ayer, D.; Thomas, M.; Foster, A. J. Drug Abus., 2018, 4 (1-4) (https://doi.org/10.21767/2471-853x.100071). 
71. Katz, D. P.; Bhattacharya, D.; Bhattacharya, S.; Deruiter, J.; Clark, C. R.; Suppiramaniam, V.; Dhanasekaran, M. Toxicol. Lett., 2014, 229 (2), pp 349-356 (http://dx.doi.org/10.1016/j. toxlet.2014.06.020).

72. Banks, M. L.; Worst, T. J.; Sprague, J. E. J. Emerg. Med., 2014, 46 (5), pp 632-642 (https://doi. org/10.1016/j.jemermed.2013.11.104).

73. Luethi, D.; Liechti, M. E. Arch. Toxicol., 2020, 94, pp 1085-1133 (https://doi.org/10.1007/s00204-02002693-7).

74. Anderson, C. J. Chem. Educ., 2005, 82 (12), 1809 (https://doi.org/10.1021/ed082p1809).

75. Smith, D. E.; Marzilli, L.; Davidson, L. D. In: Textbook of Addiction Treatment. Springer International Publishing, Cham, 2021, pp 733-756 (https://doi.org/10.1007/978-3-030-36391-8_51).

76. Lloyd, A.; Russell, M.; Blanes, L.; Somerville, R.; Doble, P.; Roux, C. Forensic Sci. Int., 2014, 242, pp 16-23 (https://doi.org/10.1016/j.forsciint.2014.06.013).

77. Rodrigues, C. H. P.; Bruni, A. T. Estudos in silico do comportamento de catinonas sintéticas com interesse forense. Master's thesis, 2018, Universidade de São Paulo, Ribeirão Preto, SP, Brazil (https://doi.org/10.11606/D.59.2019.tde-23102018-112244).

78. Zargar, T.; Khayamian, T.; Jafari, M. T. Microchim. Acta, 2018, 185, 103 (https://doi.org/10.1007/ s00604-017-2623-3).

79. Sabzehzari, M.; Ajamgard, M.; Shamlouei, H. R. Struct. Chem., 2019, 30, pp 1853-1857 (https://doi. org/10.1007/s11224-019-01316-x).

80. Kumar, V.; Kumar, P.; Pournara, A.; Vellingiri, K.; Kim, K.-H. TrAC Trends Anal. Chem., 2018, 106, pp 84-115 (https://doi.org/10.1016/j.trac.2018.07.003).

81. Jang, Y.; Jang, M.; Kim, H.; Lee, S. J.; Jin, E.; Koo, J. Y.; Hwang, I.-C.; Kim, Y.; Ko, Y. H.; Hwang, I.; Oh, J. H.; Kim, K. Chem, 2017, 3, pp 641-651 (https://doi.org/10.1016/j.chempr.2017.08.015).

82. Horáček, M.; Gyepes, R.; Císařová, I.; Kubišta, J.; Pinkas, J.; Mach, K. J. Organomet. Chem., 2010, 695, (21), pp 2338-2344 (https://doi.org/10.1016/j.jorganchem.2010.06.025).

83. Mercieca, G.; Odoardi, S.; Cassar, M.; Rossi, S. S. J. Pharm. Biomed. Anal., 2018, 149, pp 494-501 (https://doi.org/10.1016/j.jpba.2017.11.024).

84. Dhabbah, A. M. Forensic Sci. Int., 2020, 307, 110105 (https://doi.org/10.1016/j.forsciint.2019.110105).

85. Alsenedi, K. A.; Morrison, C. Anal. Methods, 2018, 10, pp 1431-1440 (https://doi.org/10.1039/ C8AY00041G).

86. Woźniak, M. K.; Banaszkiewicz, L.; Wiergowski, M.; Tomczak, E.; Kata, M.; Szpiech, B.; Namieśnik, J.; Biziuk, M. Forensic Toxicol., 2020, 38, pp 42-58 (https://doi.org/10.1007/s11419-019-00485-y).

87. Alsenedi, K. A.; Morrison, C. J. Chromatogr. B, 2018, 1076, pp 91-102 (https://doi.org/10.1016/j. jchromb.2018.01.027).

88. Gilbert, N.; Antonides, L. H.; Schofield, C. J.; Costello, A.; Kilkelly, B.; Cain, A. R.; Dalziel, P. R. V.; Horner, K.; Mewis, R. E.; Sutcliffe, O. B. Drug Test. Anal., 2020, 12, 798 (6), pp 798-811 (https://doi. org/10.1002/dta.2771).

89. Gerace, E.; Caneparo, D.; Borio, F.; Salomone, A.; Vincenti, M. J. Sep. Sci., 2019, 42 (8), pp 15771584 (https://doi.org/10.1002/jssc.201801249).

90. Loganathan, D.; Yi, R.; Patel, B.; Zhang, J.; Kong, N. Anal. Bioanal. Chem., 2021, 413, pp 21472161 (https://doi.org/10.1007/s00216-021-03182-1).

91. Pérez-Alcaraz, A.; Borrull, F.; Calull, M.; Aguilar, C. TrAC Trends Anal. Chem., 2021, 143, 116347 (https://doi.org/10.1016/j.trac.2021.116347).

92. Hulme, M. C.; Hayatbakhsh, A.; Brignall, R. M.; Gilbert, N.; Costello, A.; Schofield, C. J.; Williamson, D. C.; Kemsley, E. K.; Sutcliffe, O. B.; Mewis, R. E. Magn. Reson. Chem., 2021, mrc. 5156 (https:// doi.org/10.1002/mrc.5156).

93. Trinklein, T. J.; Thapa, M.; Lanphere, L. A.; Frost, J. A.; Koresch, S. M.; Aldstadt, J. H. Talanta, 2021, 231, 122355 (https://doi.org/10.1016/j.talanta.2021.122355). 
94. Zhao, Y.; Wu, B.; Hua, Z.; Xu, P.; Xu, H.; Shen, W.; Di, B.; Wang, Y.; Su, M. Anal. Sci., 2021 (https:// doi.org/10.2116/analsci.21P048).

95. Westphal, F.; Girreser, U.; Waldmüller, D. Drug Test. Anal., 2016, 8 (9), pp 910-919 (https://doi. org/10.1002/dta.1889).

96. Araújo, A. M.; Valente, M. J.; Carvalho, M.; da Silva, D. D.; Gaspar, H.; Carvalho, F.; Bastos, M. L.; de Pinho, P. G. Arch. Toxicol., 2015, 89, pp 757-771 (https://doi.org/10.1007/s00204-014-1278-7).

97. Sharma, V.; Kumar, R. Microchem. J., 2017, 134, pp 104-113 (https://doi.org/10.1016/j. microc.2017.05.014).

98. Gastegger, M.; Behler, J.; Marquetand, P. Chem. Sci., 2017, 8, pp 6924-6935 (https://doi.org/10.1039/ C7SC02267K).

99. Ferus, M.; Cassone, G.; Táborský, V.; Heays, A.; Petera, L.; Knížek, A.; Kalvoda, T.; Bouša, M.; Šponer, J.; Šponer, J. E.; et al. ACS Omega, 2021, 6 (22), pp 14447-14457 (https://doi.org/10.1021/ acsomega.1c01325).

100. Zancajo, V. M. R. R.; Brito, J.; Carrasco, M. P.; Bronze, M. R.; Moreira, R.; Lopes, A. Forensic Sci. Int., 2014, 244, pp 102-110 (https://doi.org/10.1016/j.forsciint.2014.08.010).

101. Spálovská, D.; Paškan, M.; Jurásek, B.; Kuchař, M.; Kohout, M.; Setnička, V. New J. Chem., 2021, 45, pp 850-860 (https://doi.org/10.1039/D0NJ05065B).

102. Milhazes, N.; Martins, P.; Uriarte, E.; Garrido, J.; Calheiros, R.; Marques, M. P. M.; Borges, F. Anal. Chim. Acta, 2007, 596 (2), pp 231-241 (https://doi.org/10.1016/j.aca.2007.06.027).

103. Christian, J. D. R. Forensic Investigation of Clandestine Laboratories. CRC Press, 2003 (https://doi. org/10.1201/9780203484548).

104. Braz, A.; Silva, C. S.; Peixoto, A. C.; Pimentel, M. F.; Pereira, G.; Braga, P. C. C. S.; Martini, A. L.; Alcântara, T. L. F. J. Raman Spectrosc., 2021, 52 (4), pp 901-913 (https://doi.org/10.1002/jrs.6074).

105. Martins, D.; Valente, H.; Pires, C. Saúde Soc. São Paulo, 2015, 24 (2), pp 646-660 (https://doi. org/10.1590/S0104-12902015000200020).

106. Pendl, E.; Pauritsch, U.; Kollroser, M.; Schmid, M. G. Forensic Sci. Int., 2021, 319, 110658 (https:// doi.org/10.1016/j.forsciint.2020.110658).

107. Pascual-Caro, S.; Borrull, F.; Aguilar, C.; Calull, M. Separations, 2020, 7, 53 (https://doi.org/10.3390/ separations7040053).

108. Wang, Y.; Shi, Y.; Yu, Y.; Chen, L.; Jiang, J.; Long, J.; Xiang, P.; Duan, G. J. Anal. Toxicol., 2021, 45 (7), pp 633-643 (https://doi.org/10.1093/jat/bkaa106).

109. Adamowicz, P. Clin. Toxicol., 2021, 59 (7), pp 648-654 (https://doi.org/10.1080/15563650.2020.184 8100).

110. Carlier, J.; La Maida, N.; Di Trana, A.; Huestis, M. A.; Pichini, S.; Busardò, F. P. Therapeutic Drug Monitoring, 2020, 42 (2), pp 205-221 (https://doi.org/10.1097/FTD.0000000000000719).

111. Santos Jr, W. J. R.; De Martinis, B. S. Bioanalysis, 2020, 12 (17) (https://doi.org/10.4155/bio-20200155).

112. Esteve-Turrillas, F. A.; Armenta, S.; de la Guardia, M. J. Chromatogr. A, 2020, 1633, 461615 (https:// doi.org/10.1016/j.chroma.2020.461615).

113. Daryanavard, S. M.; Zolfaghari, H.; Abdel-Rehim, A.; Abdel-Rehim, M. Biomed. Chromatogr., 2021, 35 (7), e5105 (https://doi.org/10.1002/bmc.5105).

114. Aldubayyan, A. A.; Castrignanò, E.; Elliott, S.; Abbate, V. Drug Test. Anal., 2021, 13 (1), pp 44-68 (https://doi.org/10.1002/dta.2990).

115. Piorunska-Sedlak, K.; Stypulkowska, K. Forensic Sci. Int., 2020, 312, 110262 (https://doi. org/10.1016/j.forsciint.2020.110262).

116. Rojkiewicz, M.; Kuś, P.; Kusz, J.; Książek, M.; Sochanik, A. Forensic Toxicol., 2020, 38, pp 481-489 (https://doi.org/10.1007/s11419-020-00525-y).

117. Sorribes-Soriano, A.; Esteve-Turrillas, F. A.; Armenta, S.; Amorós, P.; Herrero-Martínez, J. M. Anal. Chim. Acta, 2019, 1052, pp 73-83 (https://doi.org/10.1016/j.aca.2018.11.046). 
118. Tai, S.; Morrison, C. TrAC - Trends Anal. Chem., 2017, 86, pp 251-262 (https://doi.org/10.1016/j. trac.2016.11.008).

119. De Rycke, E.; Stove, C.; Dubruel, P.; De Saeger, S.; Beloglazova, N. Biosens. Bioelectron., 2020, 169, 112579 (https://doi.org/10.1016/j.bios.2020.112579).

120. Gallardo-González, J.; Baraket, A.; Bonhomme, A.; Zine, N.; Sigaud, M.; Bausells, J.; Errachid, A. Anal. Lett., 2018, 51 (3), pp 348-358 (https://doi.org/10.1080/00032719.2017.1326053).

121. Takahashi, F.; Nitta, S.; Shimizu, R.; Jin, J. Forensic Toxicol., 2018, 36, pp 185-191 (https://doi. org/10.1007/s11419-017-0388-3).

122. Teófilo, K. R.; Arantes, L. C.; Marinho, P. A.; Macedo, A. A.; Pimentel, D. M.; Rocha, D. P.; de Oliveira, A. C.; Richter, E. M.; Munoz, R. A. A.; dos Santos, W. T. P. Microchem. J., 2020, 157, 105088 (https:// doi.org/10.1016/j.microc.2020.105088).

123. Li, H.; Hu, X.; Zhao, J.; Koh, K.; Chen, H. Electrochem. Commun., 2019, 100, pp 126-133 (https:// doi.org/10.1016/j.elecom.2019.02.002).

124. Masemola, D. P.; Mafa, P. J.; Nyoni, H.; Mamba, B. B.; Msagati, T. A. J. Environ. Sci. Heal. Part B, 2020, 55 (5), pp 455-461 (https://doi.org/10.1080/03601234.2020.1713670).

125. Risoluti, R.; Gullifa, G.; Battistini, A.; Materazzi, S. Anal. Chem., 2019, 91 (10), pp 6435-6439 (https:// doi.org/10.1021/acs.analchem.9b00197).

126. Risoluti, R.; Gullifa, G.; Buiarelli, F.; Materazzi, S. Talanta, 2020, 208, 120456 (https://doi.org/10.1016/j. talanta.2019.120456).

127. Bovens, M.; Ahrens, B.; Alberink, I.; Nordgaard, A.; Salonen, T.; Huhtala, S. Forensic Sci. Int., 2019, 301, pp 82-90 (https://doi.org/10.1016/j.forsciint.2019.05.030).

128. Salonen, T.; Ahrens, B.; Bovens, M.; Eliaerts, J.; Huhtala, S.; Nordgaard, A.; Alberink, I. Forensic Sci. Int., 2020, 307, 110138 (https://doi.org/10.1016/j.forsciint.2019.110138).

129. Popovic, A.; Morelato, M.; Roux, C.; Beavis, A. Forensic Sci. Int., 2019, 302, 109911 (https://doi. org/10.1016/j.forsciint.2019.109911).

130. Ashton, C. H. Br. J. Psychiatry, 2001, 178 (2), pp 101-106 (https://doi.org/10.1192/bjp.178.2.101).

131. Amin, M. R.; Ali, D. W. Pharmacology of Medical Cannabis. In: Bukiya, A. (Ed.) Recent Advances in Cannabinoid Physiology and Pathology. Part of the Advances in Experimental Medicine and Biology book series, vol 1162. Springer, Cham., 2019, pp 151-165 (https://doi.org/10.1007/978-3-030-217372_8).

132. Howlett, A. C.; Barth, F.; Bonner, T. I.; Cabral, G.; Casellas, P.; Devane, W. A.; Felder, C. C.; Herkenham, M.; Mackie, K.; Martin, B. R.; et al. Pharmacol Rev., 2002, 54 (2), pp 161-202 (https:// doi.org/10.1124/pr.54.2.161).

133. Howlett A. C.; Abood, M. E. Adv. Pharm., 2017, 80, pp 169-206 (https://doi.org/10.1016/ bs.apha.2017.03.007).

134. Gonçalves, G. A. M.; Schlichting, L. C. R. Rev. Bras. Psiquiatr., 2014, 20 (1), pp 92-97.

135. Sarne, Y. Am. J. Drug Alcohol Abuse, 2019, 45 (6), pp 551-562 (https://doi.org/10.1080/00952990. 2019.1578366).

136. United Nations Office on Drugs and Crime. Recommended Methods for the Identification and Analysis of Synthetic Cannabinoid Receptor Agonists in Seized Materials (Revised and updated). United Nations Publication, Vienna, 2020.

137. United Nations Office on Drugs and Crime (UNODC) World Drug Report - Executive Summary: Policy Implications, United Nations Publication, Sales No. E.21.XI.8, Vienna, 2021 (https://doi. org/10.18356/a6fa3135-en).

138. Mercieca, G.; Odoardi, S.; Mestria, S.; Cassar, M.; Strano-Rossi, S. J. Sep. Sci., 2020, 43 (14), pp 2858-2868 (https://doi.org/10.1002/jssc.202000181).

139. Bordin, D. C.; Messias, M.; Lanaro, R.; Cazenave, S. O. S.; Costa, J. L. Quim. Nova, 2012, 35 (10), pp 2040-2043 (https://doi.org/10.1590/S0100-40422012001000025). 
140. França, H. S.; Acosta, A.; Jamal, A.; Romao, W.; Mulloor, J.; Almirall, J. R. Forensic Chem., 2020, 17, 100212 (https://doi.org/10.1016/j.forc.2019.100212).

141. United Nations Office on Drugs and Crime Recommended Methods for the Identification and Analysis of Cannabis and Cannabis Products. United Nations Publication, Vienna, 2013.

142. Sherma, J.; Rabel, F. J. Liq. Chromatogr. Relat. Technol., 2019, 42 (19-20), pp 613-628 (https://doi. org/10.1080/10826076.2019.1663529).

143. Dresen, S.; Ferreirós, N.; Pütz, M.; Westphal, F.; Zimmermann, R.; Auwärter, V. J. Mass Spectrom., 2010, 45 (10), pp 1186-1194 (https://doi.org/10.1002/jms.1811).

144. Andres, J.-N.; Siddiqui, H.; Fong, M. The Chemists' Gold: An Analysis of Gas Chromatography-Mass Spectrometry and Future Directions. In: Clayton, M.; Abbas, N. (Eds). Voices of Forensic Science: Are We There Yet? The Golden Standards of Forensic Science. Forensic Science Program, University of Toronto Mississauga, Mississauga, ON, Canada, 2021, pp 231-249.

145. Kneisel, S.; Westphal, F.; Moosmann, B.; Brecht, V.; Bisel, P.; Vidal, C.; Jacobsen-Bauer, A.; Bork, W.-R.; Auwärter, V. Toxichem Krimtech, 2011, 78, 465.

146. Knittel, J. L.; Holler, J. M.; Chmiel, J. D.; Vorce, S. P.; Magluilo, J.; Levine, B.; Ramos, G.; Bosy, T. Z. J. Anal. Toxicol., 2016, 40 (3), pp 173-186 (https://doi.org/10.1093/jat/bkv137).

147. Dresen, S.; Kneisel, S.; Weinmann, W.; Zimmermann, R.; Auẅarter, V. J. Mass Spectrom., 2011, 46 (2), pp 163-171 (https://doi.org/10.1002/jms.1877).

148. Musah, R. A.; Domin, M. A.; Walling, M. A.; Shepard, J. R. E. Rapid Commun. Mass Spectrom., 2012, 26 (9), pp 1109-1114 (https://doi.org/10.1002/rcm.6205).

149. Kauppila, T. J.; Flink, A.; Haapala, M.; Laakkonen, U. M.; Aalberg, L.; Ketola, R. A.; Kostiainen, R. Forensic Sci. Int., 2011, 210 (1-3), pp 206-212 (https://doi.org/10.1016/j.forsciint.2011.03.018).

150. Grabenauer, M.; Krol, W. L.; Wiley, J. L.; Thomas, B. F. Anal Chem., 2012, 84 (13), pp 5574-5581 (https://doi.org/10.1021/ac300509h).

151. Gottardo, R.; Chiarini, A.; Dal Prà, I.; Seri, C.; Rimondo, C.; Serpelloni, G.; Armato, U.; Tagliaro, F. J. Mass Spectrom., 2012, 47 (1), pp 141-146 (https://doi.org/10.1002/jms.2036).

152. Ernst, L.; Schiebel, H. M.; Theuring, C.; Lindigkeit, R.; Beuerle, T. Forensic Sci. Int., 2011, 208 (1-3), pp e31-e35 (https://doi.org/10.1016/j.forsciint.2011.03.020).

153. Bersani, F. S.; Corazza, O.; Albano, G.; Valeriani, G.; Santacroce, R.; Posocco, F. B. M.; Cinosi, E.; Simonato, P.; Martinotti, G.; Bersani, G.; Schifano, F. Biomed Res. Int., 2014, 2014, Article ID 734749, (https://doi.org/10.1155/2014/734749).

154. de Morais, D. R.; da Cunha, K. F.; Rodrigues, T. B.; Lanaro, R.; Barbosa, L. M.; Zacca, J. J.; Eberlin, M. N.; Costa, J. L. Forensic Sci. Int., 2020, 309, 110184 (https://doi.org/10.1016/j.forsciint.2020.110184).

155. Moreira, A. M. S.; de Oliveira, H. L.; Allochio Filho, J. F.; Florez, D. H. Â.; Borges, M. M. C.; Lacerda, V.; Romão, W.; Borges, K. B.; et al. TrAC Trends Anal. Chem., 2019, 114, pp 260-277 (https://doi. org/10.1016/j.trac.2019.02.034).

156. Andreasen, M. F.; Telving, R.; Rosendal, I.; Eg, M. B.; Hasselstrøm, J. B.; Andersen, L. V. Forensic Sci. Int., 2015, 251, pp e1-e8 (https://doi.org/10.1016/j.forsciint.2015.03.012).

157. Kristofic, J. J.; Chmiel, J. D.; Jackson, G. F.; Vorce, S. P.; Holler, J. M.; Robinson, S. L.; Bosy, T. Z. J. Anal. Toxicol., 2016, 40 (6), pp 466-472 (https://doi.org/10.1093/jat/bkw035).

158. Zuba, D.; Sekuła, K.; Buczek, A. Forensic Sci. Int., 2013, 227 (1-3), pp 7-14 (https://doi.org/10.1016/j. forsciint.2012.08.027).

159. Seo, J.-Y.; Hur, K.-H.; Ko, Y.-H.; Kim, K.; Lee, B.-R.; Kim, Y.-J.; Kim, S.-K.; Kim, S.-E.; Lee, Y.-S.; Kim, H.-C.; Lee, S.-Y.; Jang, C.-G. Brain Res. Bull., 2019, 152, pp 19-26 (https://doi.org/10.1016/j. brainresbull.2019.07.002).

160. United Nations Office on Drugs and Crime. Rapid Testing Methods of Drugs of Abuse. United Nations publication, Vienna, 1994. 
161. Souza, G. A. Identificação e determinação de novas substâncias psicoativas em amostras de selos por técnicas voltamétricas usando eletrodo de diamante dopado com boro. Master's dissertation, 2018, University Federal of Vales do Jequitinhonha e Mucuri, Diamantina, MG, Brazil.

162. Davidson, J. T.; Jackson, G. P. Forensic Chem., 2019, 14, 100160 (https://doi.org/10.1016/j. forc.2019.100160).

163. Morini, L.; Bernini, M.; Vezzoli, S.; Restori, M.; Moretti, M.; Crenna, S.; Papa, P.; Locatelli, C.; Osculati, A. M. M.; Vignali, C.; Groppi, A. Forensic Sci. Int., 2017, 279, pp e1-e6 (https://doi.org/10.1016/j. forsciint.2017.08.028).

164. Magalhães, L. de O. Desenvolvimento de métodos quimiométricos para triagem de novas substâncias psicoativas em selos utilizando técnicas espectroscópicas na região do infravermelho. Doctoral thesis, 2019, Institute of Chemistry, University of Brasília, Brasília, DF, Brazil.

165. Magalhães, L. O.; Arantes, L. C.; Braga, J. W. B. Microchem. J., 2019, 144, pp 151-158 (https://doi. org/10.1016/j.microc.2018.08.051).

166. Custódio, M. F.; Magalhães, L. O.; Arantes, L. C.; Braga, J. W. B. J. Braz. Chem. Soc., 2021, 32 (3), pp 513-522 (https://doi.org/10.21577/0103-5053.20200205).

167. Nikolaou, P.; Papoutsis, I.; Stefanidou, M.; Spiliopoulou, C.; Athanaselis, S. Drug Chem. Toxicol., 2015, 38, pp 113-119 (https://doi.org/10.3109/01480545.2014.911882).

168. Poklis, J. L.; Raso, S. A.; Alford, K. N.; Poklis, A.; Peace, M. R. J. Anal. Toxicol., 2015, 39 (8), pp 617-623 (https://doi.org/10.1093/jat/bkv073).

169. Suzuki, J.; El-Haddad, S. Drug Alcohol Depend., 2017, 171, pp 107-116 (https://doi.org/10.1016/j. drugalcdep.2016.11.033).

170. Zawilska, J. B. Front. Psychiatry, 2017, 8, p 110 (https://doi.org/10.3389/fpsyt.2017.00110).

171. Baumann, M. H.; Tocco, G.; Papsun, D. M.; Mohr, A. L.; Fogarty, M. F.; Krotulski, A. J. Brain Sci., 2020, 10 (11) (https://doi.org/10.3390/brainsci10110895).

172. Marchei, E.; Pacifici, R.; Mannocchi, G.; Marinelli, E.; Busardò, F.; Pichini, S. Trends Anal. Chem., 2018, 102, pp 1-15 (https://doi.org/10.1016/j.trac.2018.01.007).

173. Armenian, P.; Vo, K. T.; Barr-Walker, J.; Lynch, K. L. Neuropharmacology, 2018, 134, pp 121-132 (https://doi.org/10.1016/j.neuropharm.2017.10.016).

174. Jannetto, P. J.; Helander, A.; Garg, U.; Janis, G. C.; Goldberger, B.; Ketha, H. Clin. Chem., 2019, 65 (2), pp 242-253 (https://doi.org/10.1373/clinchem.2017.281626).

175. Elbardisy, H.; Foster, C.; Cumba, L.; Antonides, L.; Gilbert, N.; Schofield, C. Anal. Methods, 2019, 11, pp 1053-1063 (https://doi.org/10.1039/C9AY00009G).

176. Fernández, M.; Wille, S.; Jankowski, D.; Hill, V.; Samyn, N. Forensic Sci. Int., 2020, 307, 110137 (https://doi.org/10.1016/j.forsciint.2019.110137).

177. Nan, Q.; Ping, X.; Baohua, S.; Xianyi, Z.; Yan, S.; Fenyun, S. J. Chromatogr. B, 2019, 1124, pp 82-99 (https://doi.org/10.1016/j.jchromb.2019.05.025).

178. Sisco, E.; Verkouteren, J.; Staymates, J.; Lawrence, J. Forensic Chem., 2017, 4, pp 108-115 (https:// doi.org/10.1016/j.forc.2017.04.001).

179. Green, T. C.; Park, J. N.; Gilbert, M.; McKenzie, M.; Struth, E.; Lucas, R.; Clarke, W.; Sherman, S. G. Int. J. Drug Policy, 2020, 77, 102661 (https://doi.org/10.1016/j.drugpo.2020.102661).

180. Prekupec, M. P.; Mansky, P. A.; Baumann, M. H. J. Addict. Med., 2017, 11 (4), pp 256-265 (https:// doi.org/10.1097/ADM.0000000000000324).

181. Bergh, M.; Oiestad, A.; Baumann, M.; Bogen, I. Int. J. Drug Policy, 2021, 90, 103065 (https://doi. org/10.1016/j.drugpo.2020.103065).

182. Angelini, D.; Biggs, T.; Maughan, M.; Feasel, M.; Sisco, E.; Sekowski, J. Forensic Sci. Int., 2019, 300, pp 75-81 (https://doi.org/10.1016/j.forsciint.2019.04.019).

183. Moosmann, B.; Auwärter, V. Designer Benzodiazepines: Another Class of New Psychoactive Substances. In: Maurer, H.; Brandt, S. (Eds). New Psychoactive Substances. Handbook of Experimental Pharmacology, vol. 252. Springer, Cham, 2018, pp 383-410 (https://doi.org/10.1007/164_2018_154). 
184. Cole, J. O.; Chiarello, R. J. J. Psychiatr. Res., 1990, 24 (S2), pp 135-144 (https://doi.org/10.1016/00223956(90)90045-R).

185. Elliott, S.; Evans, J. Forensic Sci. Int., 2014, 243, pp 55-60 (https://doi.org/10.1016/j. forsciint.2014.04.017).

186. United Nations Office on Drugs and Crime. World Drug Report 2014. United Nations Publication, Sales No. E.14.XI.7, New York, 2014.

187. Zawilska, J. B.; Wojcieszak, J. Neurotoxicology, 2019, 73, pp 8-16 (https://doi.org/10.1016/j. neuro.2019.02.015).

188. Fudin, H. R.; Babin, J. L.; Hong, L. T.; Ku, J.; May, A. L.; Wisner, A.; Scott Hall, F.; Ray, S. D., 2018, pp 29-89 (https://doi.org/10.1016/bs.seda.2018.08.015).

189. Manchester, K. R.; Lomas, E. C.; Waters, L.; Dempsey, F. C.; Maskell, P. D. Drug Test. Anal., 2018, 10 (1), pp 37-53 (https://doi.org/10.1002/dta.2211).

190. https://www.ukat.co.uk/benzodiazepines/ [Accessed 6 September 2021].

191. Schmitz, A. Ment. Heal. Clin., 2016, 6 (3), pp 120-126 (https://doi.org/10.9740/mhc.2016.05.120).

192. Beharry, S.; Gibbons, S. Forensic Sci. Int., 2016, 267, pp 25-34 (https://doi.org/10.1016/j. forsciint.2016.08.013).

193. Høiseth, G.; Tuv, S. S.; Karinen, R. Forensic Sci. Int., 2016, 268, pp 35-38 (https://doi.org/10.1016/j. forsciint.2016.09.006).

194. United Nations Office on Drugs and Crime. World drug report 2017: Global overview of drug demand and supply. United Nations publication, Sales No. E.17.XI.6, Vienna, 2017.

195. Mahmood, Z.; Muhammad, S.; Arshad, N.; Ma, T.; Mz, Q.; Usman, M. J. Appl. Pharm., 2018, $10,3$. Available at: https://www.longdom.org/open-access/a-new-colorimetric-identification-of-benzodiazepinesusing-cobalt-thiocyanate-as-reagent-1920-4159-1000265.pdf [Accessed September 2021].

196. Qriouet, Z.; Qmichou, Z.; Bouchoutrouch, N.; Mahi, H.; Cherrah, Y.; Sefrioui, H. J. Anal. Methods Chem., 2019, 2019, Article ID 2035492 (https://doi.org/10.1155/2019/2035492).

197. Szatkowska, P.; Koba, M.; Kośliński, P.; Wandas, J.; Bączek, T. Cent. Eur. J. Chem., 2014, 12 (10), pp 994-1007 (https://doi.org/10.2478/s11532-014-0551-1).

198. Dror, I. E. Anal. Chem., 2020, 92 (12), pp 7998-8004 (https://doi.org/10.1021/acs.analchem.0c00704).

199. Ahmad, S. M.; Nogueira, J. M. F. Talanta, 2019, 199, pp 195-202 (https://doi.org/10.1016/j. talanta.2019.02.004). 